\title{
Vegetation Ecology of Debris-Covered Glaciers (DCGs)_Site Conditions, Vegetation Patterns and Implications for DCGs Serving as Quaternary Cold- and Warm-Stage Plant Refugia
}

\author{
Thomas Fickert $^{1, *(\mathbb{D}}$, Donald Friend ${ }^{2}$, Bruce Molnia ${ }^{3}{ }^{,}$Friederike Grüninger ${ }^{4}$ and Michael Richter $^{5}$ \\ 1 German Alpine Club, Baden-Wuerttemberg Branch, Nature Conservancy Unit, Rotebühlstr. 59 A, \\ 70178 Stuttgart, Germany \\ 2 Department of Geography, Minnesota State University, 206 Morris Hall, Mankato, MN 56001, USA; \\ donald.friend@mnsu.edu \\ 3 US Geological Survey, Reston, VA 20192, USA; glacier1@verizon.net \\ 4 TNL Environmental Planning, Hochstraße 21, 92637 Weiden in der Oberpfalz, Germany; \\ friederike.grueninger@posteo.de \\ 5 Institute for Geography, Friedrich-Alexander-University, Wetterkreuz 15, 91058 Erlangen, Germany; \\ sairecabur@posteo.de \\ * Correspondence: thomas.fickert@posteo.de
}

\section{check for}

updates

Citation: Fickert, T.; Friend, D.;

Molnia, B.; Grüninger, F.; Richter, M.

Vegetation Ecology of Debris-

Covered Glaciers (DCGs) —Site

Conditions, Vegetation Patterns and Implications for DCGs Serving as

Quaternary Cold- and Warm-Stage

Plant Refugia. Diversity 2022, 14, 114.

https://doi.org/10.3390/

d14020114

Academic Editor: Michael Wink

Received: 16 January 2022

Accepted: 2 February 2022

Published: 5 February 2022

Publisher's Note: MDPI stays neutral with regard to jurisdictional claims in published maps and institutional affiliations.

Copyright: (C) 2022 by the authors. Licensee MDPI, Basel, Switzerland. This article is an open access article distributed under the terms and conditions of the Creative Commons Attribution (CC BY) license (https:// creativecommons.org/licenses/by/ $4.0 /)$

\begin{abstract}
Scientific interest in debris-covered glaciers (DCGs) significantly increased during the last two decades, primarily from an abiotic perspective, but also regarding their distinctive ecology. An increasing body of evidence shows that, given a minimum of debris thickness and sufficient substrate stability, DCGs host surprisingly diverse plant assemblages, both floristically and structurally, despite being obviously cold and in parts also highly mobile habitats. As a function of site conditions, floristic composition and vegetation structure, DCGs represent a mosaic of environments, including subnival pioneer communities, glacier foreland early- to late-successional stages, morainal locations, and locally, even forest sites. On shallow supraglacial debris layers, cryophilous alpine/subnival taxa can grow considerably below their common elevational niche due to the cooler temperatures within the root horizon caused by the underlying ice. In contrast, a greater debris thickness allows even thermophilous plant species of lower elevations to grow on glacier surfaces. Employing the principle of uniformitarianism, DCGs are assumed to have been important and previously undocumented refugia for plants during repeated Quaternary cold and warm cycles. This review and recent study summarize the current knowledge on the vegetation ecology of DCGs and evaluates their potential function as plant habitat under ongoing climate warming.
\end{abstract}

Keywords: high mountain biogeography; climate change ecology; refugia; niche heterogeneity

\section{Introduction}

DCGs are globally distributed landforms, occurring in mountain ranges of all major climatic zones, from subpolar into the tropics, with a spatial concentration at midlatitudes [1,2]. DCGs are more common in mountainous terrain compared to polar ice sheets, because unglaciated rock faces and scree slopes serving as sources for both, debris and vegetation, are limited in polar environments. Estimates of mountain glacier area covered by supraglacial debris range from $4.4 \%$ [1] to $7.3 \%$ [2], and the relative share of DCGs is increasing as clean-ice glaciers shrink globally under current climate warming $[3,4]$ —apart from regional exceptions such as the "Karakoram anomaly" [5]. At the same time rockfall events in high cirques are increasing due to destabilized slopes from intensified freeze-thaw cycles, downwasting glaciers and permafrost degradation [6-8].

DCGs might resemble rock glaciers by shape and appearance (Figure 1a), but actually are different landforms regarding their formation, a fact that is not consistently respected in the scientific literature [9-13]. Here we treat DCGs sensu Kirkbride [14] as "true" 
glaciers partly to almost fully overlain by a mantle of rock material, in the ablation zone in particular (Figure 1a-d). Rock glaciers, in contrast, consist of a perennially frozen mixture of ice (40-70\%) and coarse rock material, slowly moving down-valley. Ground ice within rock glaciers commonly originates by congelation [11] but can also have a glacial origin, i.e., an evolution from debris-covered glaciers cannot be excluded $[12,15,16]$ (Figure 1e). Recently, Anderson et al. [17] highlighted that there is a continuum between clean-ice glaciers, debris-covered glaciers and rock glaciers.
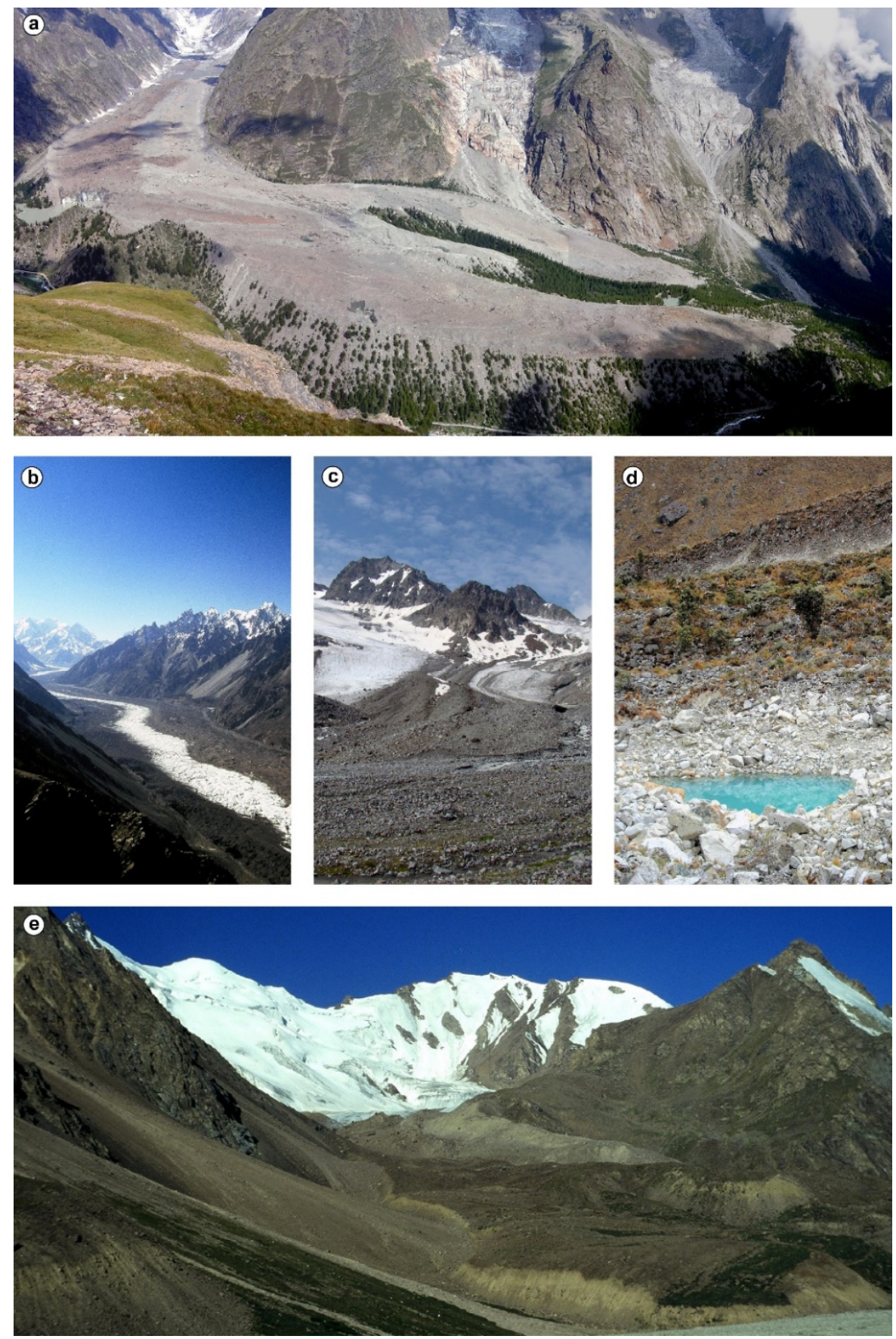

Figure 1. Aspects of DCGs: (a) fully covered Miage Glacier (European Alps, Italy); (b) debris cover restricted to the lateral margins on Batura Glacier (Karakorum, Pakistan); (c) debris cover originating from medial moraines on Jamtalferner (European Alps, Austria); (d) supraglacial lake on debriscovered Kinzl Glacier (Peruvian Andes); (e) rock glacier of most likely glacial origin in front of a clean-ice glacier (Sailiskji Alatau, Kazakhstan) (photos: (a,d) M. Richter; (b,c,e) T. Fickert). 
At the beginning of the 21st century it was noted: " ... debris covered glaciers comprise a significant fraction of the global population of glaciers and despite their relatively common occurrence, they have not been well studied" ([18], p. 261). Scientific interest in DCGs has significantly increased since then. There have been at least 500 publications on the subject with the majority focusing on the abiotic (i.e., glaciological, hydrological and geomorphological, along with natural hazard and mapping related issues, Figure 2). As supraglacial debris modifies the energy balance of glacier surfaces, DCGs show a different behavior with regard to glacier mass balance than clean-ice glaciers in times of climate warming [19-25]. In general, a thin layer of debris enhances melting rates due to a lowered albedo, while a thicker debris cover insulates glacier ice, reduce ablation and slows mass loss considerably [26,27]. However, contradicting observations of very similar surface elevation change rates for debris-covered and clean-ice glaciers are reported from High Mountain Asia, which are referred to as "debris-covered (glacier) anomaly" [27-29], but the underlying reasons are not yet fully understood [30]. In addition, efforts to enhance mapping accuracy were intensified, for glacier monitoring archives such as the Randolph Glacier Inventory [31,32], the World Glacier Monitoring Service [33], the Global Land Ice Measurements from Space initiative [34,35] and the Glacier Thickness Database [36,37]. Identifying an exact differentiation between DCGs and other landforms with similar spectral signature outside the glacier boundary is crucial to reduce bias in glacier area change estimations [38-43].

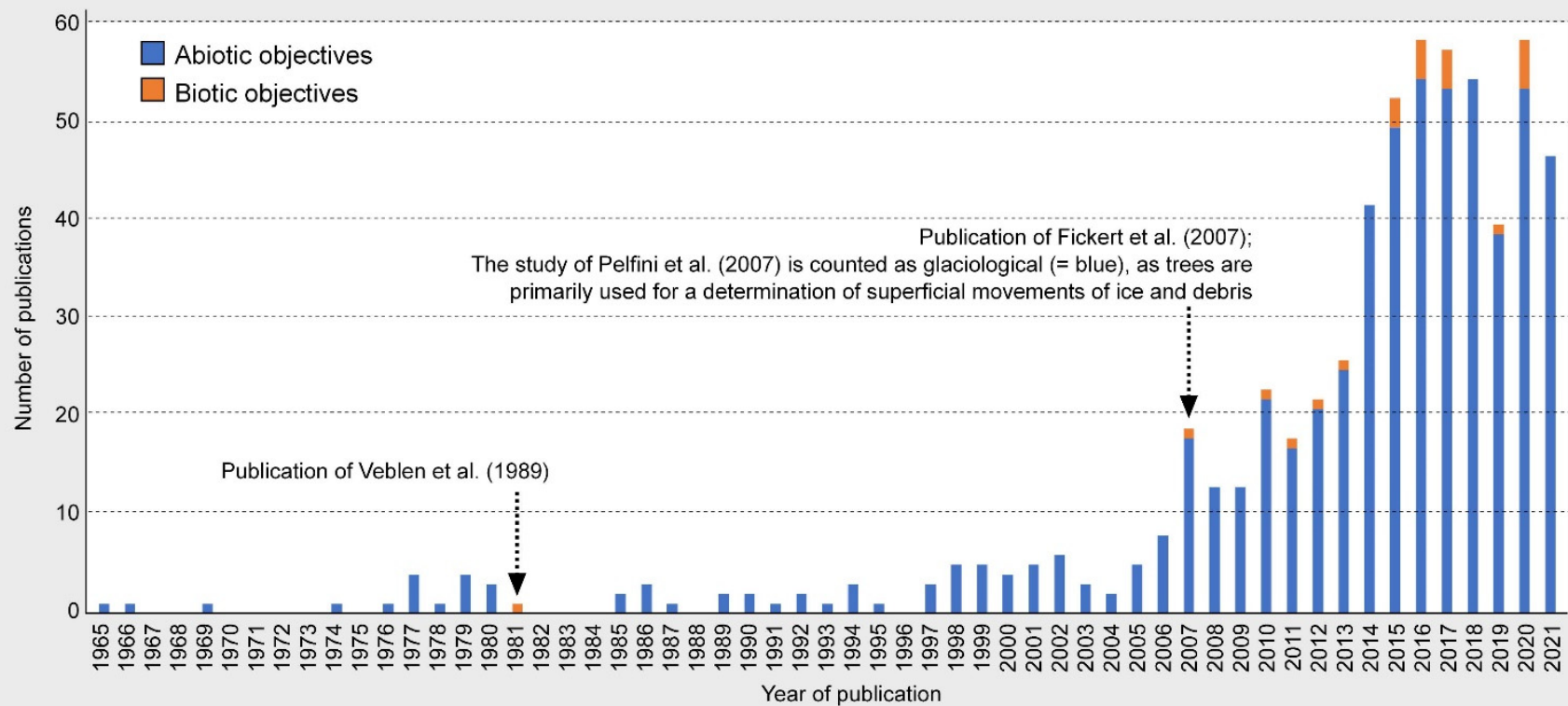

Figure 2. Bibliometric search (as of 10/2021) in the "Dimensions" Database for English language publications including the keyword "debris-covered glacier" in title or abstract. Matches were screened for objective and classified into publications with a primarily abiotic (i.e., glaciological, hydrological, geomorphological, climatological and mapping issues) and with a primarily biotic focus (i.e., flora, fauna, microbes and interactions). Papers dealing exclusively with rock glaciers, with a paleo perspective (i.e., Pleistocene, early Holocene) or with related features on Mars are excluded.

Increasing attention is also paid to DCGs from an ecological perspective, including a focus on flora [44-50], fauna [48,51-55], microbes [56] and interactions between different organism groups [57] (Figure 2). The increasing ecological interest on DCGs is also related to the fact that these landforms were recognized as potential refugia for plants (and other organisms) during warm and cold stages in the past $[44,45,47,53,54,58]$. This has implications in space and time for post-glacial recolonization patterns [45], for primary succession in glacier forelands $[59,60]$ and for the survival of cryophilous taxa under cur- 
rent climate warming due to the thermal inertia of DCGs $[47,53,54]$. Early notes on plant growth on DCGs date back well into the late 19th and 20th century. They come from all around the globe (for the Alps [61-65]; for Scandinavia and Iceland [59,66]; for Alaska and Canada [67-75]; for Southern Chile [76]; for the Himalaya [77,78]), including reports about mature forests with stem-diameters of more than $50 \mathrm{~cm}(\mathrm{DBH})$ on more than a dozen debris-covered glaciers in southcentral Alaska, including Bering, Malaspina, Fairweather and Yakataga Glaciers. (Figure 3, [41]). With the exception of [76], all of these reports are observational rather than quantitative studies.

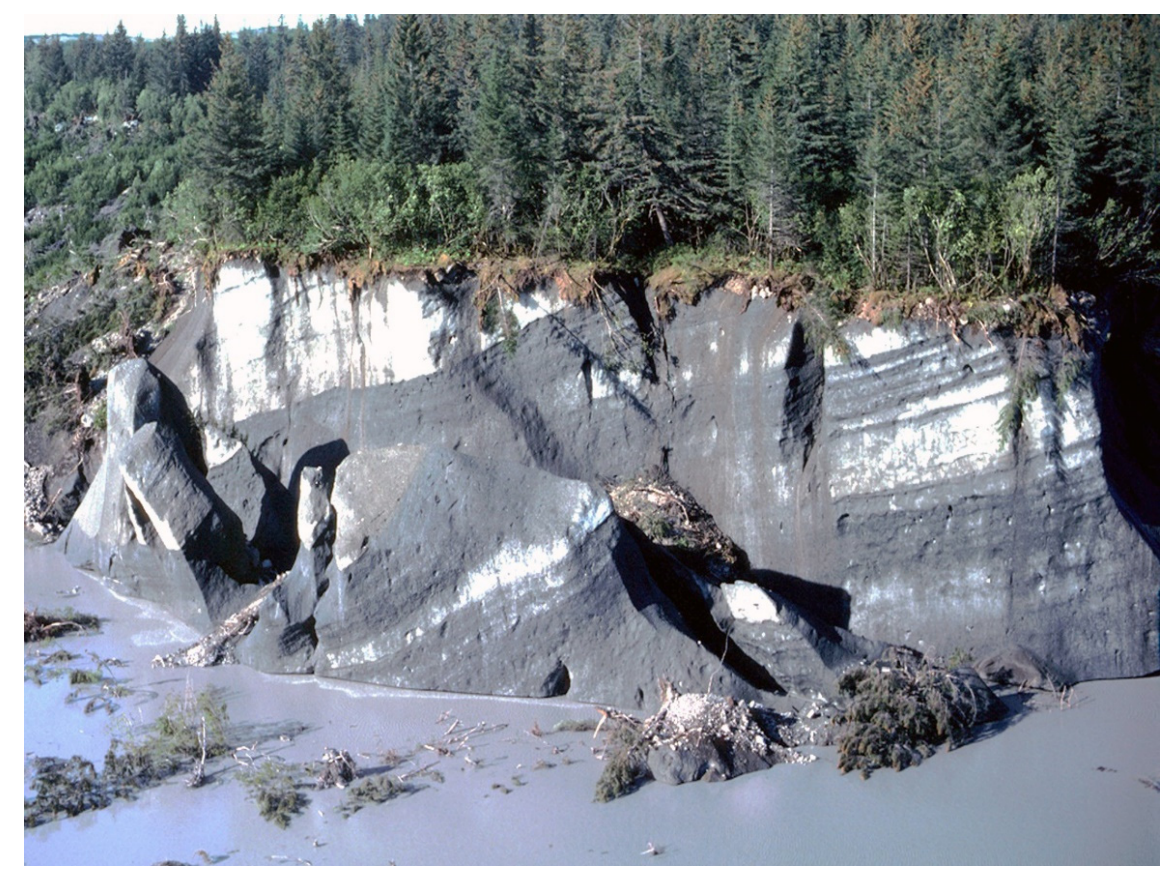

Figure 3. North-looking oblique aerial photograph of part of the vegetation-covered, stagnant ice terminus of Malaspina Glacier at Sitkagi Bluffs. The cliff of stagnant ice is approximately $15-20 \mathrm{~m}$ high, topped by a thin debris layer. A dense forest, composed of alders, willows, and conifers is rooted in this glacial sediment layer. As the ice melts, the trees topple into the lagoon. Maximum tree height is $>15 \mathrm{~m}$. The banding on the ice surface is composed of a thin drape of sediment deposited by meltwater (photo: B. F. Molnia in the 1980s).

One of the earlier accounts on plant growth on DCGs employing systematic vegetation sampling was our paper titled "Did debris-covered glaciers serve as Pleistocene refugia for plants? A new hypothesis derived from observations of recent plant growth on glacier surfaces", published in Arctic, Antarctic and Alpine Research in 2007 [45]. This publication was pioneering at the time it was published, as it included both phytosociological sampling on the debris mantled glacier surface of Carbon Glacier on Mount Rainier (Washington, DC, USA), together with short-term microclimatic measurements and determination of debris thickness and particle size spectra to allow for a rough ecological interpretation of the vegetation patterns found. In addition, the paper presented unconventional ideas about the survival of plants under a different climate in the past. This publication catalyzed a more intense engagement with the ecology of DCGs, carried out primarily by a group of Italian scientists from different disciplines in the European Alps [46,47,49,50,53,54,57], but also additional sources provide new insights into the ecology of DCGs and other cold rocky landforms $[48,58]$. Thus, we believe it is the right time for summarizing the current ecological knowledge about these distinctive habitats.

This paper is based on an extensive screening of published literature. It discusses general aspects of DCGs as plant habitat, the ecological heterogeneity within and between DCGs, and their function as potential cold and warm stage plant refugia. To further illustrate and support our original hypotheses $[44,45]$, we also report results from additional 
research on three mid-latitude DCGs, namely Carbon Glacier on Mount Rainier (Cascade Range, Washington, DC, USA), Miage Glacier (European Alps, Italy, one of the best studied DCGs in the world) and Lang Glacier (European Alps, Switzerland), along with new observations made on additional DCGs across the globe. These three model DCGs terminate in the montane (low- to mid-elevation forests), subalpine (i.e., below treeline) and alpine (i.e., above treeline) environments, respectively. To not distract from this review, Appendix A describes our materials and methods.

\section{Origin of Debris Cover and Its Effect on Glacier Movement and Glacier Mass Balance}

DCGs come in different types with regard to distribution, thickness and arrangement of supraglacial debris (Figure 1, [79]). Their surface is commonly characterized by mounds and hollows, locally disrupted by ice cliffs, thermokarst ponds and supraglacial lakes, acting as points of origin for enhanced ice melt. Particularly intriguing features of DCGs are so-called ice sails, pyramid-shaped clean-ice sections protruding the debris layer, which are especially common in the Karakoram [80,81]. Debris cover on glacier surfaces derives from rock falls and landslides originating from destabilized rock faces and debris slopes most commonly in cirques of deeply incised glacial valleys after glacier melt, after permafrost degradation, by earthquakes in seismically active mountain regions, and/or from existing medial and eroded lateral moraines [6,8,82-85] (Figure 4a). Additional debris sources include periglacial (solifluction), fluvial or aeolian sediment-transport processes, basal thrusting, as well as the melt-out of englacial debris [17,21,30,85-87] (Figure 4a).

a)

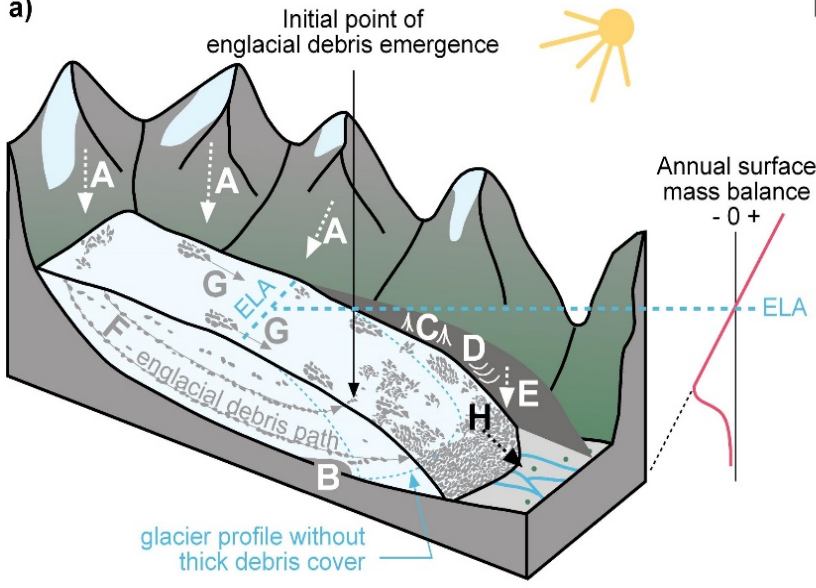

b)

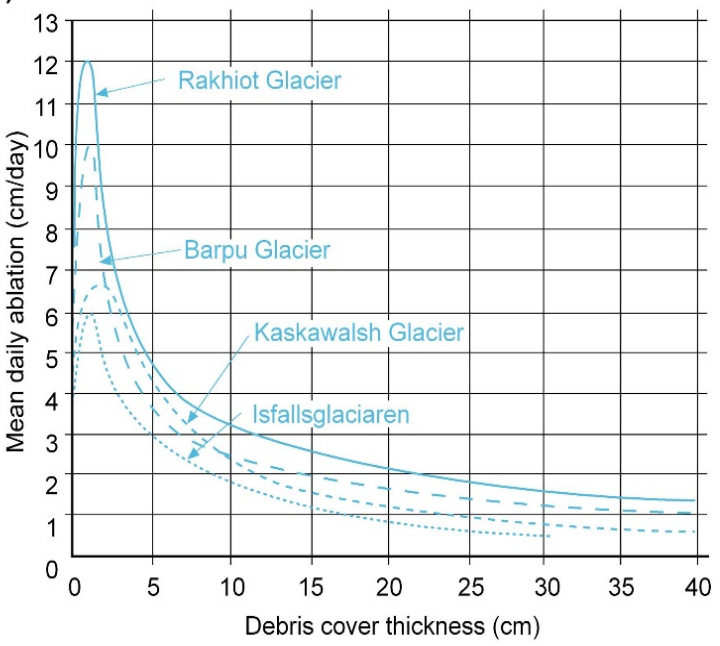

Figure 4. (a) Schematic diagram displaying debris supply processes, debris fluxes and debris features on DCGs: rock falls and landslides from surrounding walls and slopes (A); basal thrusting (B); debris flows (C), solifluction (D) and rock falls (E) from lateral moraines; debris transport (within (F) and upon the glacier $(\mathrm{G})$ ), debris concentration near the glacier terminus and eventual debris transfer to the glacier foreland $(\mathrm{H})$; a debris cover surpassing a critical thickness has a significant effect on the annual surface mass balance of a glacier by reducing the ablation and consequently the ice discharge and length reduction (redrawn from $[21,85,86]$; (b) relationship between debris cover thickness and measured mean daily ablation on different DCGs (adapted from [88]).

Supraglacial debris might cover the entire glacier surface (Figure 1a), or is concentrated in particular regions depending on the debris origin: on the lateral glacier margins, if rockfalls from the valley slopes and/or the lateral moraines are the prime debris sources (Figure 1b); or in the center, if one or more medial moraines are the prime debris sources (Figure 1c). In the case of piedmont glaciers protruding from larger glacier networks, the commonly unglaciated outer margins of mountain ranges deliver debris by rockfalls (e.g., Malaspina Glacier in Figure S1). 
Debris thickness may be as little as a couple of millimeters but may reach more than two meters [27]. The supraglacial debris has significant effects on the mass balance of glaciers and on flow dynamics. While a thin debris cover enhances melt rate due to reduced surface albedo compared to clean-ice glaciers and consequently a higher absorption of solar radiation, a supraglacial debris mantle of a couple of centimeters or more significantly reduces melt rate and glacier mass loss as heat transfer to the upper edge of the ice body is reduced $[27,89,90]$. The critical debris thickness separating the two opposing glaciological controls is around $2 \mathrm{~cm}$ ([89], Figure 4b), although substrate color may cause deviations from this value in either direction.

Generally, debris thickness on DCGs increases down-glacier towards the termini due to a "conveyor-belt-like nature of the glacier surface in the ablation zone (debris can typically only be added but not removed)", as Anderson and Anderson point out ([91], p. 1). The debris thickening on the lower parts of DCGs make debris-covered glacier tongues slow moving or even stagnant [26]. Thus, DCG termini are commonly located at lower elevations than termini of clean-ice glaciers, under otherwise equal settings, and termini reaching below alpine (i.e., thermal) tree line are common. At the upper margin of the debris cover, in contrast, thickness is often less than the critical threshold, thus increasing melt occurs there. As a result, DCGs often have convex to concave debris thickness profile towards the glacier terminus, which is ablation controlled up-glacier and velocity controlled downglacier [91]. Over time, DCG profiles as a whole become concave by slow downwasting of the glacial surface [85], favoring the formation of supraglacial meltwater ponds as drainage is topographically impeded (Figure 1d).

\section{DCGs as Habitats for Plants}

As observations, reports and phytosociological samples from DCGs demonstrate, a shallow debris mantle of a few centimeters can host surprisingly diverse vegetation, both floristically and structurally (Figure 5, [44,45,47,49,74,76]). This is not intuitive at first glance, as slowly moving DCGs are cold and, at least in up-glacier locations, mobile habitats, offering plants (and other organisms) an environment far from welcoming. The underlying ice bestows temperatures rather low for plant roots to thrive, and can initiate both passive (i.e., caused by motion of the underlying ice) and active debris movement (i.e., caused by the hummocky supraglacial debris topography) [92] that creates considerable mechanical stress for plants by constant disturbance from shifting debris.

\subsection{Physical Setting of DCGs}

The fact that a broad array of different plant species is able to grow on DCG surfaces indicates that the seemingly challenging issues for plant establishment and growth such as substrate mobility, low soil temperature or limited root horizon are offset by other factors facilitating plant growth. Supraglacial debris cover is commonly a mixture of fine- and coarse-grained (up to boulder size) material, similar to that found in recently deglaciated glacier forelands. A sufficient amount of fine-grained substrate is crucial for retaining water essential for plant growth and to allow plants to set roots, while larger rocks often serve as "safe sites" for colonizing species [93] and act as stable spots in a loose unconsolidated surrounding. In addition, such safe sites provide a more favorable microclimate from earlier snow melt, a longer growing season and/or warmer temperatures while at the same time larger rocks also create shadow preventing plants from overheating during heat waves [94]. Thus, both fine and coarse substrates support plant growth, each one in a different way. This was documented in our original study where particle size analyses of soil samples collected from the debris layer on Carbon Glacier showed no significant correlation between the states of vegetation (i.e., species numbers or ground cover) and the amount of coarse debris particles [45]. More important than the grain size distribution is the thickness of the debris layer, i.e., the spacing between the root horizon and the underlying ice, as direct contact between roots and ice adversely affects plants physiological processes and commonly leads to stunted growth forms and/or death of plants [44]. 

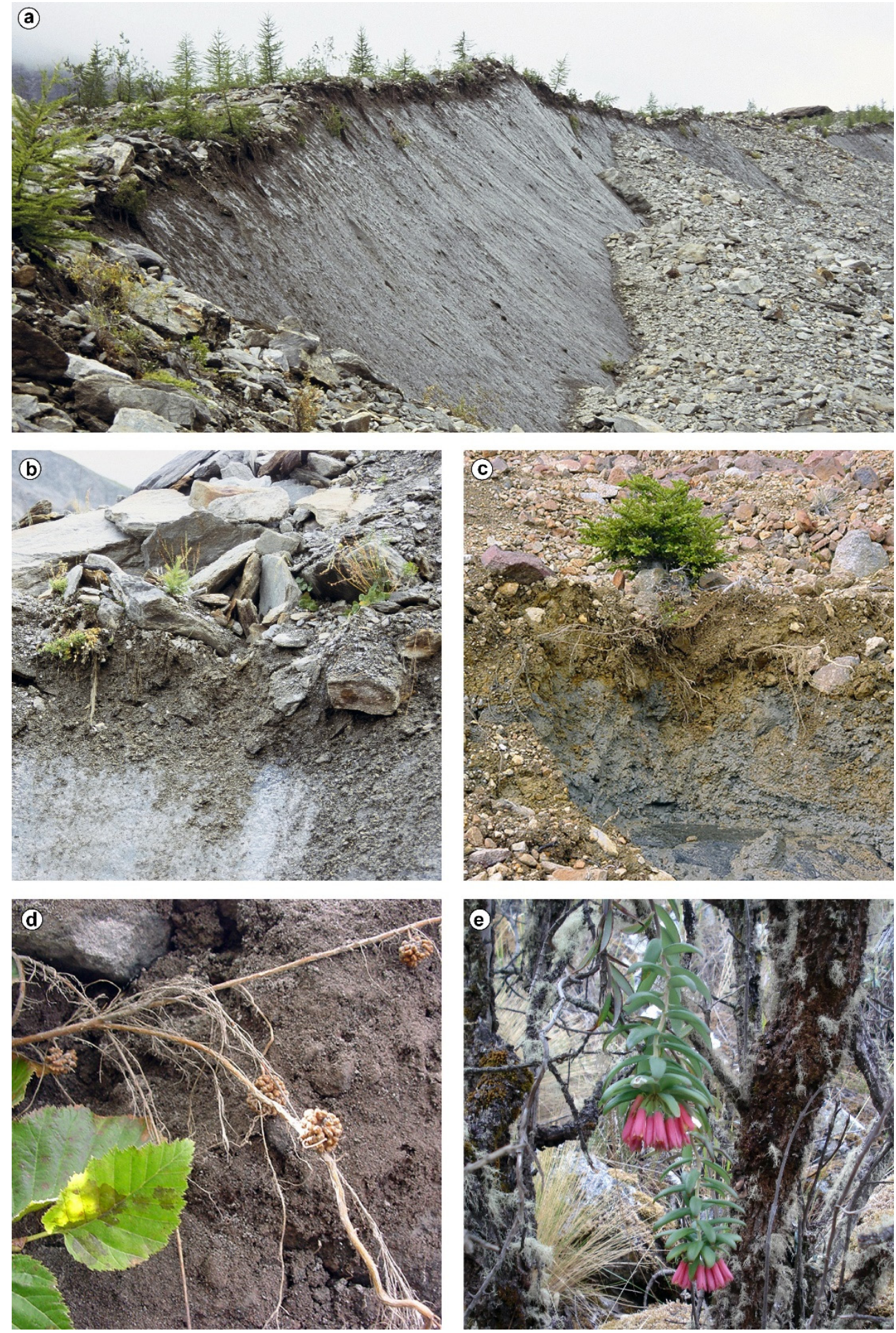

Figure 5. Aspects of plant growth on debris-covered glacier surfaces: (a) Larix decidua dominated plant community on Miage Glacier (European Alps, Italy); (b) detail view of the contact zone of ice and plants (amongst others: Oxyria digyna, Cerastium uniflorum and a Larix decidua seedling) on debriscovered Miage Glacier (European Alps, Italy); (c) Nothofagus dombeyi on debris-covered Ventisquero Blanco (Andes, Southern Chile)—note the gleyic soil due to water saturation caused by the underlying ice; (d) Alnus viridis ssp. sinuata on debris-covered Carbon Glacier with the symbiotic actinomycete filamentous nitrogen-fixing bacterium Frankia alni on its roots (Mount Rainier, Washington, DC, USA); (e) the epiphytic lily-of-the-Incas Bomarea albimontana on a Polylepis-tree growing on the supraglacial debris of Kinzl Glacier (Peruvian Andes) (photos: (a,b) Th. Fickert; (c,d) F. Grüninger; (e) M. Richter). 
There are some analogies between supraglacial debris layers and recently deglaciated glacier forelands with regard to environmental setting, species composition and vegetation structure [47]. A major difference, however, is that on moving glaciers the debris layer is quite mobile, while the coarse morainal debris left by receding glaciers is commonly settled and stabilized by early colonizers within a short period of time $[95,96]$. In fact, where DCGs move over subglacial rock outcrops or bend while following the topography of glacial valleys, crevasses and serac zones with highly mobile debris layers occur, impairing the chances for plant establishment. The lower parts of DCGs, however, are often stagnant and characterized by a slow downwasting of the glacier body causing a lowering of the overlaying debris layer without major effects on the substrate stability and the debris layer is thus readily available for plant colonization.

Besides substrate characteristics, microclimate is a major control of plant growth [97]. As plant growth on DCGs occurs in a broad range of environments from high to low latitudes (e.g., the Coast Ranges of Alaska to the Cordillera Blanca in Peru) and under very variable moisture conditions (perhumid-maritime in the Andes of Southern Chile or the US Cascade Range, to arid continental in the Northwestern Karakoram or the Eastern Pamir), macroclimate seems not to be a major control for presence or absence of supraglacial vegetation. However, microclimate is a major control of plant growth and plays an important role for colonization and survival, as well as for species composition and groundcover development on DCGs. Depending on the thickness of the debris layer and the color of the material present, the heat flow from above into the root horizon and the cooling effects from the underground ice variably overlap (Figure 6).

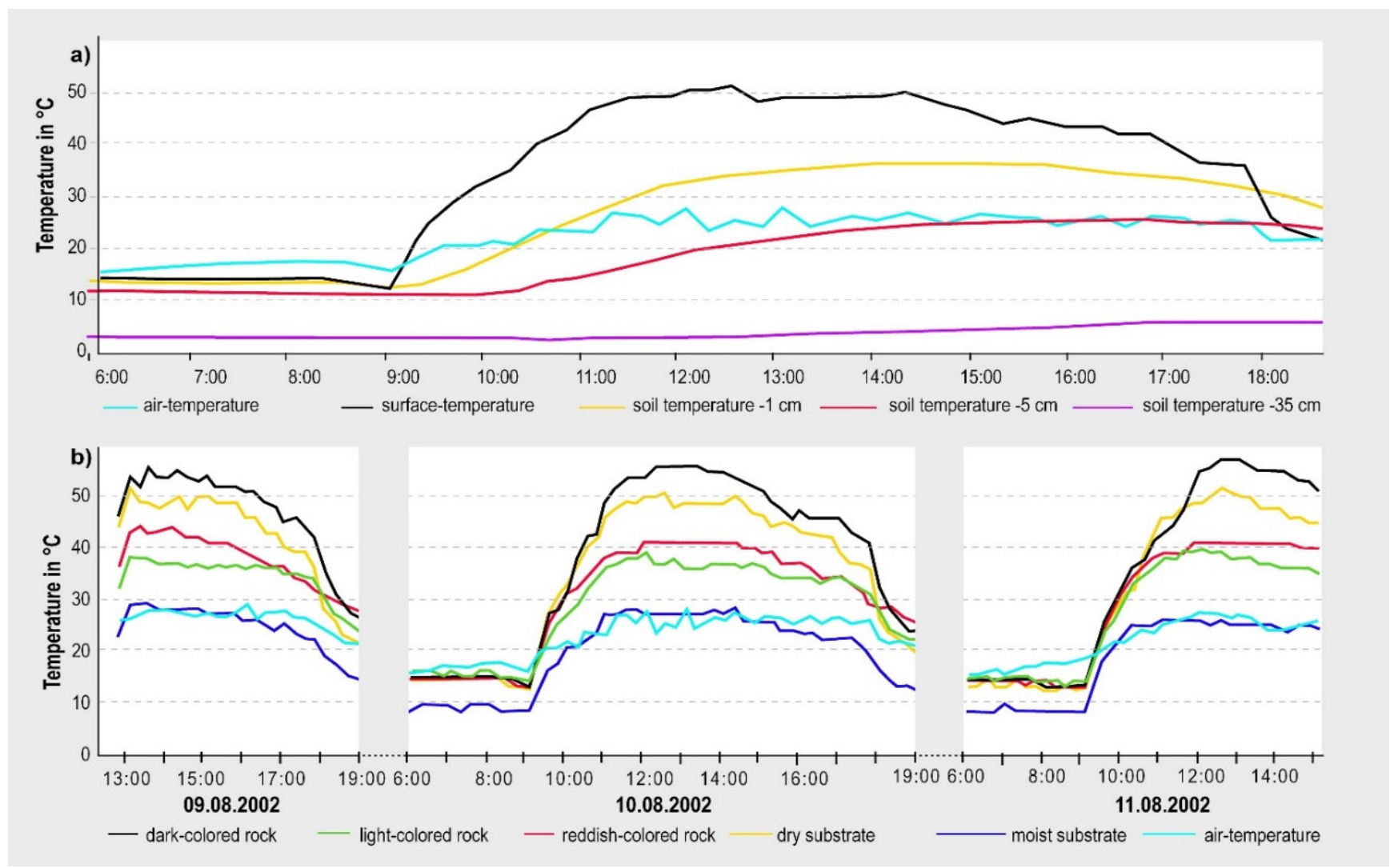

Figure 6. (a) Air temperatures $(2 \mathrm{~m})$, debris surface temperature and soil temperature at various depths, recorded on 10 August 2002 with cloudless skies on Carbon Glacier; (b) surface temperatures of differently colored debris together with air temperature recorded with cloudless skies on Carbon Glacier between 9 August and 11 August 2002 (redrawn and modified from [45]).

Short term measurements of soil temperatures at different depths on Carbon Glacier at Mount Rainier (Washington, DC, USA) at a study site with a debris cover of $40 \mathrm{~cm}$ 
showed that no substantial cooling effects exist in the upper layers down to about $-35 \mathrm{~cm}$ (i.e., $5 \mathrm{~cm}$ above the ice) (Figure 6a). At depths of -1 and $-5 \mathrm{~cm}$, heat flow is slightly delayed but follows the daily course of air and surface temperatures and offers a rather warm root horizon. At a depth of $-35 \mathrm{~cm}$, daily temperatures fluctuate between 3 and $7{ }^{\circ} \mathrm{C}$, indicating that heat flow from the surface is recognizable with slightly increasing temperatures in late afternoon; thus, even at greater depths, heat transfer from the debris surface is evident (Figure 6a). Measurements of surface temperatures on differently colored substrates on the debris layer of Carbon Glacier (Figure 6b) revealed high microclimatic niche variability in close proximity. On dry and/or dark substrates, daytime ground surface temperatures of more than $50{ }^{\circ} \mathrm{C}$ were measured, a temperature potentially lethal for cryophilous plants [94], yet they survive in areas of wet substrates and/or a thin debris cover which allow for cooler root zone temperatures. Those same high surface temperatures offer growth conditions for thermophilous taxa from lower elevations on areas where surface debris is thicker. In general, wide daily temperature fluctuations are a common surface characteristic of DCGs $[45,47,49]$.

\subsection{Source Areas and Dispersal Pathways of Plants Colonizing DCGs}

Potential source areas for plants colonizing DCGs are plant communities in the wider surrounding area. These vary depending on the location of the glacier tongue, which is a function of climate, aspect, elevation and topography, along with size of the glacier accumulation zone and the debris thickness governing ice melt in the ablation zone. The vast majority of plant species colonizing the supraglacial debris is anemochochorous, i.e., wind dispersed (Figure 7), reaching the glacier surface by mesoscale diurnal mountainvalley wind systems [98]. Anemochorous species commonly show a leptokurtic diaspore dispersal behavior [99], i.e., most diaspores are deposited in close proximity to the mother plant, and only few are transported over longer distances during strong wind events; thus, the chances to reach a particular location decrease with distance to the source area.

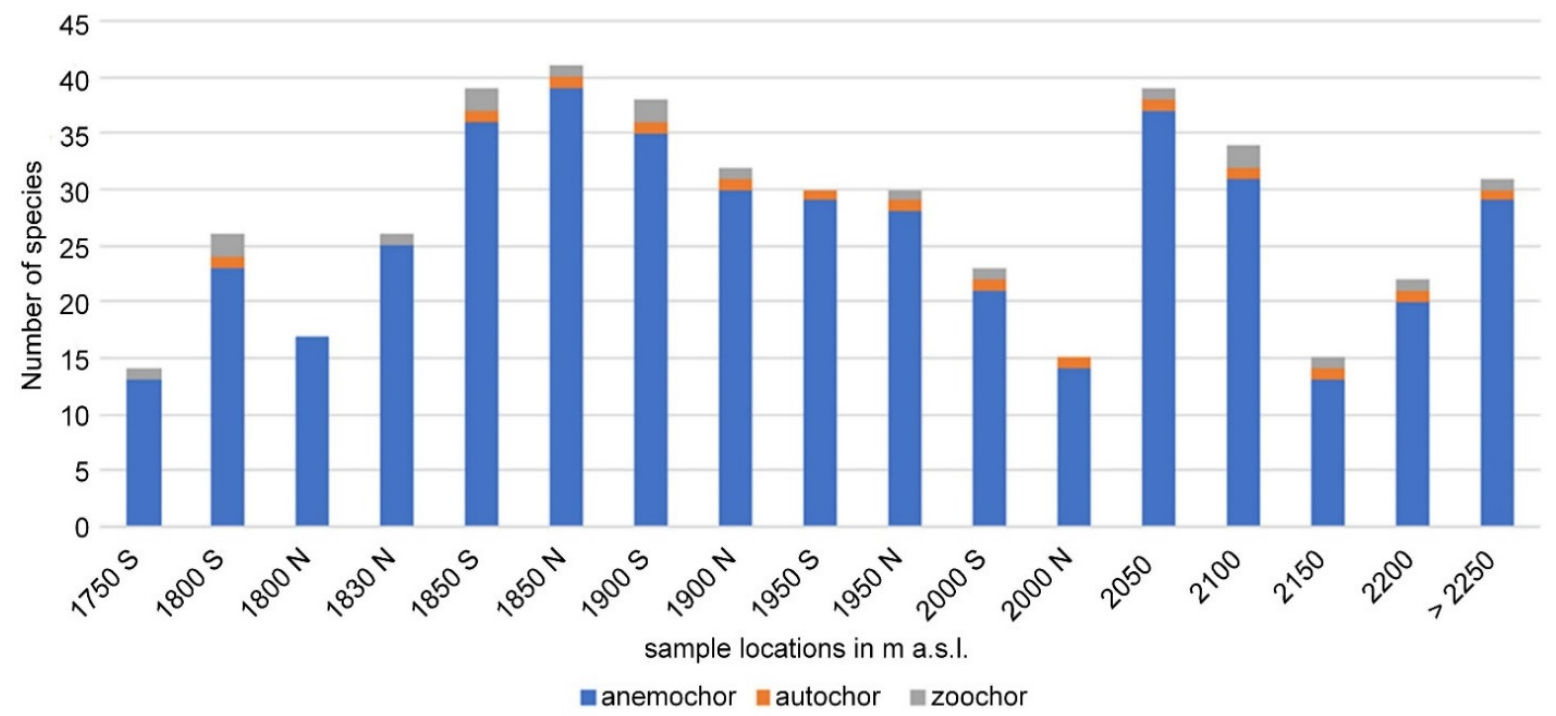

Figure 7. Predominant seed dispersal pathways (according to [100]) of species growing on Miage Glacier: anemochor $=$ wind dispersed, autochor $=$ without external forces by the plant itself, zoochor $=$ dispersed by animals.

Figure 8 shows the provenances of species growing on "montane" Carbon Glacier (i.e., located within montane conifer forests), on "subalpine" Miage Glacier (i.e., located within the subalpine treeline ecotone), and on "alpine" Lang Glacier (i.e., located in the alpine belt above treeline). While on all three glaciers a broad range of species from montane (=low elevation) to subnival (=high elevation) origin grow side by side, it becomes very clear that plant communities of the immediate surroundings contribute the most to the 
DCGs species composition; at Carbon Glacier, half of the species encountered are low- to mid-elevation taxa (montane and montane-subalpine), while high-elevation taxa (alpine and alpine-subnival) are underrepresented. In contrast, on Lang Glacier, which terminates above alpine treeline, three-quarters of the taxa growing on its surface originate from plant communities of the treeline ecotone upwards. Miage Glacier shows a more balanced contribution of species originating from different elevational belts. Either way, even on Lang Glacier some taxa from lower elevations occur (e.g., Larix decidua well above tree line) if debris cover is sufficiently thick, while on Carbon and Miage glaciers several highelevation taxa benefit from lowered soil temperatures at locations with shallow debris cover and consequently occur well below their usual lower distribution limit. For example, on Carbon Glacier the alpine species Luetkea pectinata and the alpine-subnival pioneer Oxyria digyna grow virtually side by side with montane conifers such as Pseudotsuga menziesii var. menziesii or Tsuga heterophylla. On Miage Glacier the subnival species Ranunculus glacialis, one of the highest ascending vascular plants in the European Alps and commonly found between 2300 and $4200 \mathrm{~m}$ a.s.l, occurs as low as $1850 \mathrm{~m}$ a.s.l., together with montane Salix mysinifolia or the subalpine conifer Larix decidua.
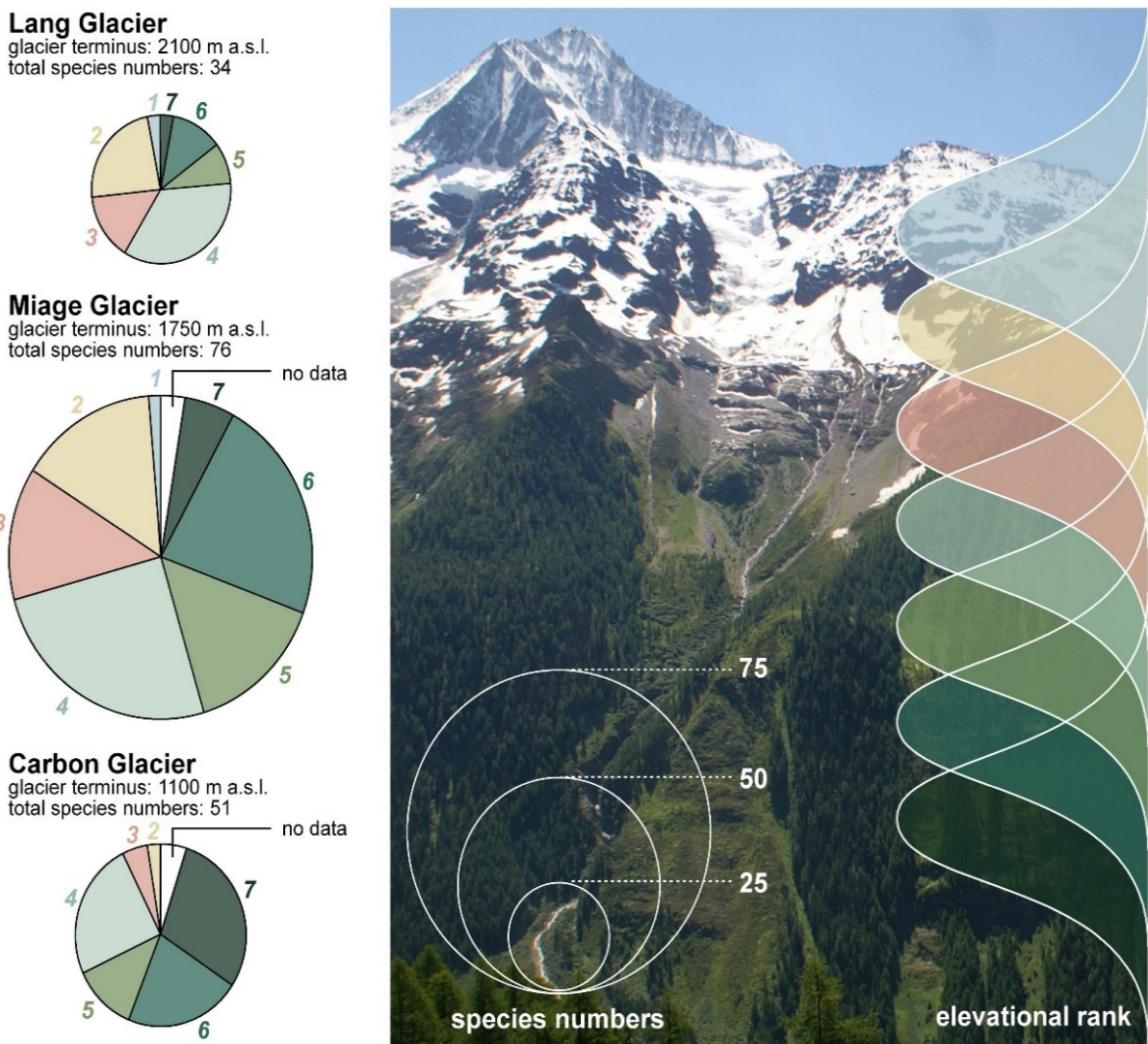

1 subnival

2 alpine - subnival

3 alpine

4 subalpine - alpine

5 subalpine

6 montane - subalpine

7 montane

Figure 8. According to their primarily temperature-determined distribution along the elevational gradient, plant species refer to different elevational belts, here montane to subnival. The species distribution can be used as an ecological indicator for the respective temperature preferences, so for each plant species a particular elevational rank value can be assigned, here 1 (=subnival) to 7 (=montane) (according to information given in [101,102]). The pie charts on the left show the relative contribution of species from different provenances for the "montane" Carbon Glacier, the "subalpine" Miage Glacier and the "alpine" Lang Glacier.

To answer the question of whether plants from a particular plant community in the immediate surroundings of a DCG are superior in colonizing the supraglacial debris, vegetation sampling on Carbon Glacier was supplemented by samples from forest locations and scree slopes in close proximity to the glacier. A canonical correspondence analysis (CCA, Figure 9) including samples from the supraglacial debris as well as from forest and 
scree slope sites, shows, not surprisingly, that scree slope samples are well separated from the forest sites due to a low floristic similarity. The DCG samples are located between these two diverging environments, with some samples floristically more similar to forests sites, some to scree slope sites and some with a co-occurrence of species present in both habitats (including Alnus viridis ssp. sinuata, Poa secunda, Polystichum muntium or Saxifraga ferruginea var. ferruginea). Thus, depending on debris properties, a wide range of site characteristics, some more closely related to scree slopes and others more to forest sites, allow for plants from very different provenances to find suitable habitats on supraglacial debris. Consequently, a clear attribution of supraglacial vegetation to phytosociological units (plant communities, associations) is difficult [49].

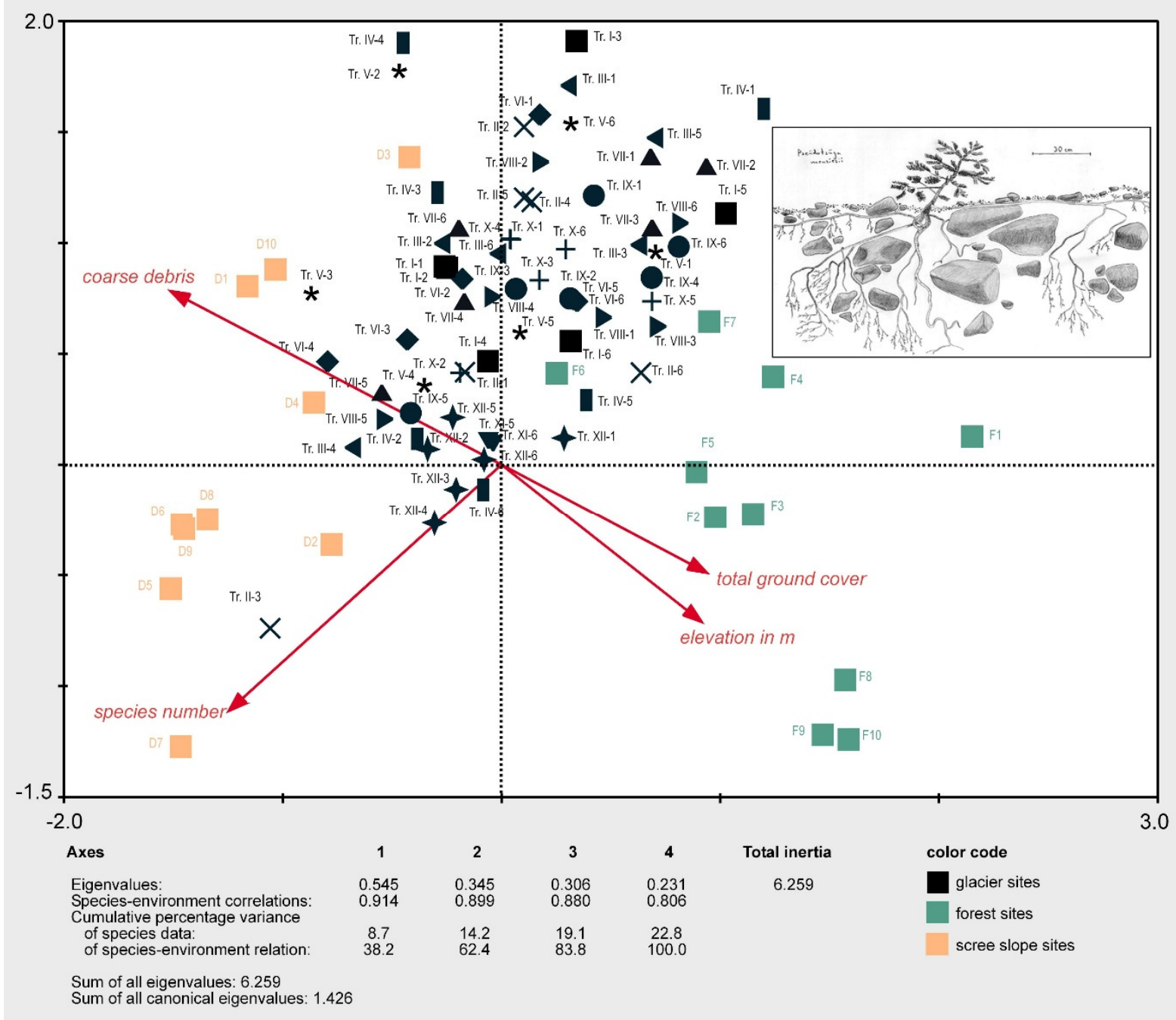

Figure 9. A canonical correspondence analysis (CCA) ordination biplot showing the floristic similarity of samples on the debris-covered surface of Carbon Glacier on Mount Rainier (Washington, DC, USA) in relation to samples from forest and scree slope sites in the immediate surroundings. The inset shows the disproportionally long roots of a small Pseudotsuga menziesii var. menziesii treelet growing on the supraglacial debris of Carbon Glacier (drawing by M. Richter).

Plant growth on debris-covered glacier surfaces is not restricted to a highly specialized set of plants. Rather, most available species tolerating underground ice and substrate mobility to some degree potentially can colonize supraglacial debris $[47,49]$. A shallow and wide-spreading root-system (Figure 9, inset), which is a common feature in high mountain plant species [103] seems to be beneficial in terms of keeping distance to the ice, thereby preventing negative effects on the plants' physiological processes and to withstand the 
permanent rearrangement of the substrate. Only very few taxa have special adaptations such as Alnus species which lives in symbiosis with the actinomycete filamentous nitrogenfixing bacterium Frankia alni (Figure 5d), and hence has a better nutrient supply.

The colonization of supraglacial debris has certain analogies to the colonization of glacier forelands [47]. In both settings, successful vegetation development requires three important steps (according to [104]): (1) plants, or rather their diaspores, have to get there, i.e., the colonization process itself; (2) plant seeds reaching the debris-covered glacier surface have to establish, i.e., successful germination; and (3) once established, the plants have to persist, grow and spread, i.e., survival. The prevailing anemochorous plant species set up an "autochthonous" vegetation type with in situ germination of seeds carried primarily by wind from the surroundings to the debris layer. This colonization pathway, however, is not the only one. Often plants reach the glacier surface by landslides from vegetated lateral moraines and/or adjacent bordering mountain slopes [76], setting up a patchier, "allochthonous" vegetation type [44]. Plant colonization via this pathway is particularly common on the tropical Kinzl Glacier in the Cordillera Blanca of the Peruvian Andes, where most of the plants growing on the debris-covered glacier surface, including small tree individuals of Polylepis sericea (Figure 1d), are derived from landslides originating from Little Ice Age (LIA) moraines after substantial post-LIA downwasting of the debriscovered glacier surface [105]. Once established, even those plant species that reached the supraglacial debris via long distance dispersal now propagate on the glacier surface and persist through a cycle of a slow downward migration via glacier flow and upward dispersal of diaspores by valley winds without the necessity of further stochastic long distance dispersal events.

\subsection{Spatiotemporal Plant Diversity Patterns on DCGs}

DCGs can host a large number of different plant species. Among the three case studies presented here (i.e., Carbon Glacier, Miage Glacier and Lang Glacier), the highest total species number (76 taxa) and highest species number per $100 \mathrm{~m}^{2}$ sample location (up to 25 species) are encountered at Miage Glacier. This is most likely due to its intermediate subalpine location, which allows for an overlap of species from low and high elevations (Figure 8). On montane Carbon Glacier and alpine Lang Glacier, chances for high- and low-elevation species, respectively, to reach and successfully establish on the debris layer are less than at Miage Glacier's intermediate elevation, consequently species numbers are lower (Carbon Glacier: 41 taxa, Lang Glacier: 34 taxa, [44]). Similar counts are reported at Belvedere Glacier in the European Alps (31 taxa, [49]), at Ventisquero Blanco in Southern Chile (37 taxa, [44]), and at Hailuogou and Gonga Gomba Glaciers in the Chinese Gonga Shan (32 taxa and 38 taxa, respectively, [44]). This astonishing species richness on DCGs is linked to the highly variable microclimate and surface characteristics with sunny, dry, and/or coarse-grained habitats occurring side-by-side with shady, humid, and/or fine-grained habitats, offering growth conditions for both, xerophytic, or at least desiccation tolerant species, together with more hygrophilous and/or cryophilous species in close proximity.

Structural diversity of the supraglacial vegetation is affected by the location of a DCG relative to the respective elevational zonation, too. On DCGs terminating within the forested belt such as Carbon and Miage Glaciers, different life-forms including trees and higher shrubs (i.e., micro- to macrophanerophytes) co-occur and ground cover values are as high as $20 \%$ (though highly variable), while on higher elevation Lang glacier ground cover is much less (rarely exceeding $0.3 \%$ ), with herbs and subshrubs (i.e., hemicryptophytes and chamaephytes) being the predominant life-forms (Figure 10a). The overall highest structural complexity on a DCG was observed on the tropical Kinzl Glacier. Because the debris-covered portion of the glacier is located some $500 \mathrm{~m}$ below the local treeline at $4800 \mathrm{~m}$ a.s.l., small tree individuals of Polylepis sericea, taller shrub species (Berberis lutea, Gynoxys oleifolia), several dwarf to medium-sized shrubs (Baccharis genistelloides, Phyllactis rigida, Loricaria ferruginea, Diplostephium foliosissimum, Vaccinium floribundum), perennial 
herbs (e.g., the ferns Cheilanthes pruinata and Elaphoglossum engelii, the club moss Lycopodium crissum, the herbs Gentiana prostrata, Castilleja nubigena, Neobartsia diffusa, Senecio nivalis and Werneria nubigena) as well as grasses (Stipa ichu and Deyeuxia ovata) are present. Further supraglacial oddities on Kinzl Glacier include the cushion cactus Austrocylindropuntia floccosa, the terricolous orchid Aa mathewsii and even epiphytes such as Bomarea albimontana (Figure 5e) are found growing on older Polylepis-trees.

Apart from locations close to the glacier front or ice cliffs where debris shifting activity is more pronounced, species richness, ground cover, and structural complexity expressed by the co-occurrence of different life-forms, is generally higher in the less mobile lower elevation sections of DCGs. Up-glacier floristic and structural diversity successively decreases due to combined effects of a change in elevation, a reduction of debris cover and a faster glacier velocity, and thus increased debris cover mobility (Figure 10). On Carbon Glacier, for example, a steep serac zone around $1450 \mathrm{~m}$ is responsible for a decrease in ground cover and species richness. On Miage Glacier a similar pattern appears, where the glacier turns from a southern into an eastward flow direction (Figure 1a). In both cases, ground cover and species richness decrease toward the high mobility zone, and increase again once the high mobility zone is passed (Figure 10a,b). Caccianiga et al. [47] also found that glacier velocity $(0.3-16 \mathrm{~m} / \mathrm{yr}$.), which affects debris stability, and elevation were the best predictors for species richness on Miage Glacier. Lang Glacier, in contrast, shows a continuously decreasing ground cover and species richness with increasing elevation; this is likely related to a decreasing debris thickness and to increasingly adverse growth conditions on the glacier surface, better suited for high elevation species as expressed by the decreasing elevational rank score S (Figure 10c).

Besides spatial gradients in plant diversity patterns, temporal changes during vegetation development, i.e., succession, can be assumed to occur on debris-covered glacier surfaces. However, as scientific engagement in supraglacial vegetation is a rather recent phenomenon, no data on long-term vegetation dynamics or successional trajectories are available. Tree ages determined by dendrochronological methods allow for a rough estimate of the date of their first arrival, which occurred on some Alaskan glaciers in the second half of the 19th century, which is post Little Ice Age [67-69,71]. The same is documented on Casa Pangue Glacier in Southern Chile from the early 20th century [76] and on Miage Glacier in the European Alps the oldest trees established around the middle of the 20th century [46]. On Casa Pangue and Miage Glacier no indications for different successional stages exist yet, but Stephens [71] describes an earlier Sitka alder (Alnus crispa ssp. sinuata) stage which is eliminated later by a Sitka spruce (Picea sitchensis) stage for Kushtaka Glacier in Alaska where plant colonization started earlier. This pattern resembles successional stages described by Lawrence [107] from Alaskan glacier forelands, where an earlier Alnus sinuata dominated successional stage is also replaced by a late successional Picea sitchensis stage.

This, again, underpins ecological similarities between recently deglaciated glacier forelands and DCGs. A repeated vegetation sampling in the Alpine glacier foreland of Jamtalferner (Silvretta, Austria) in 2016 and 2021, provides some insights on the pace of the early colonization dynamics on stagnant DCG termini (Figure 11). These sample sites were placed a couple of meters in front of the ice margin in 2016 and deemed as recently deglaciated as they became ice-free only one to two years prior to sampling. In fact, these samples are still underlain by ice, as later indicated by high resolution elevation models, which show an ongoing lowering of the surface elevation due to melt-out of the underlying ice [108]. The ice does not seem to be dead ice, rather it is still connected to the clean-ice glacier several tens of meters up-valley. Thus, these sites represent an early-stage colonization of stagnant DCG terminus. The resurvey in 2021 indicates a highly dynamic colonization with exponentially increasing ground cover values and species numbers (Figure 11), comparable to recently deglaciated glacier foreland samples $[60,95,109,110]$. While this location may not be representative of the dynamics on a moving DCG with high substrate mobility and ongoing stress for plants by the constant rearrangement of debris, it does demonstrate that the stagnant termini of DCGs are characterized by progressive vegetation development, i.e., succession, and that those sites can be important refugia for plants. 


\section{\# of Carbon Glacier}

samples: 66666666666626

a)

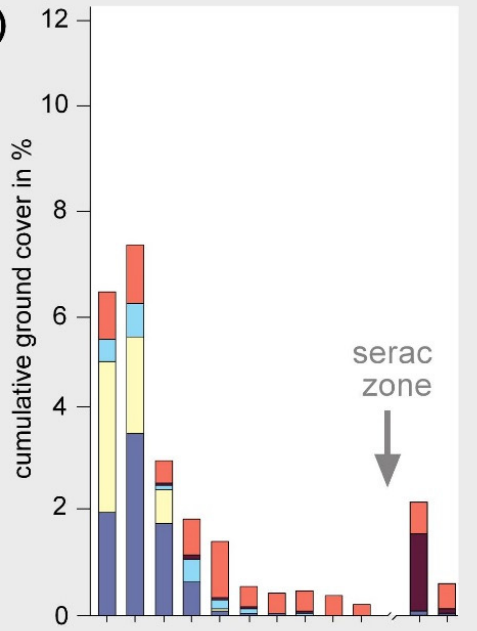

b)
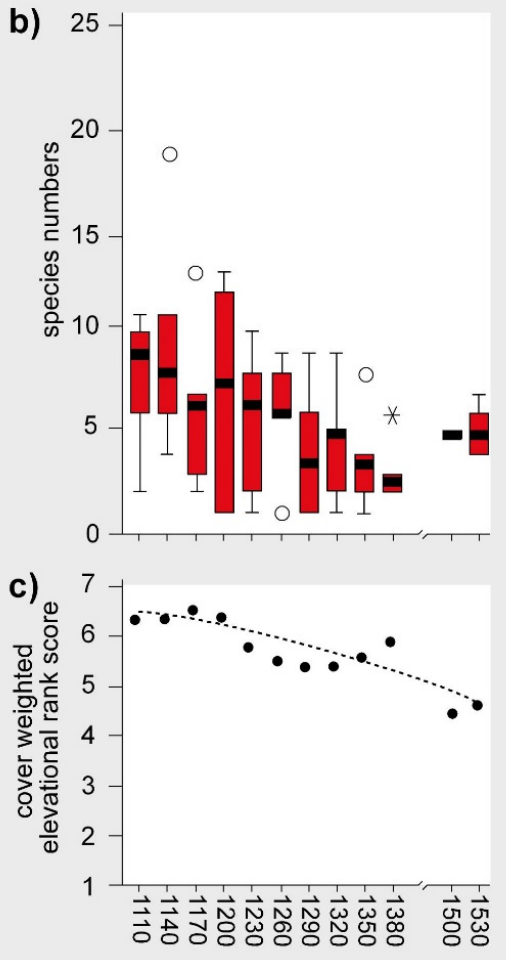

elevation in $\mathrm{m}$

\section{Miage Glacier}

33325555555576555
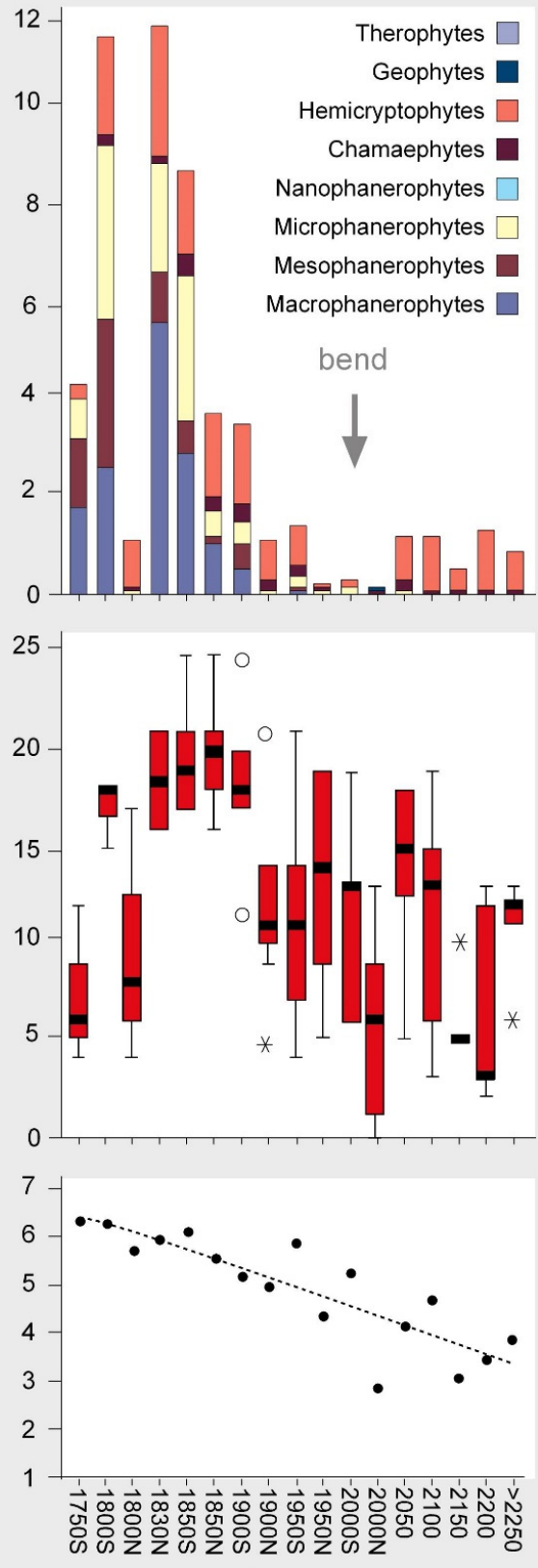

elevation in $\mathrm{m}$
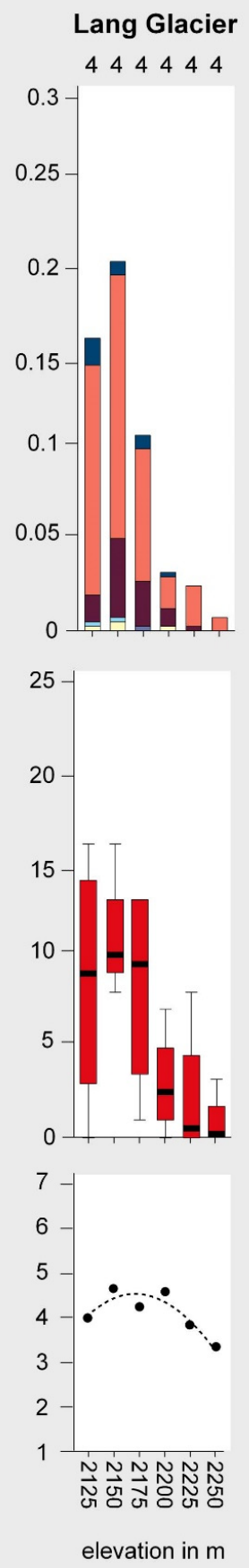

Figure 10. Gradual changes in vegetation structure and diversity measures from the glacier terminus upwards for the three mid-latitude DCGs-Carbon Glacier (terminating in the montane belt), Miage Glacier (terminating in the subalpine belt) and Lang Glacier (terminating in the alpine belt): (a) Life-form spectra, showing the contribution of individual life-forms to the mean total ground cover of vascular plants per sample location. (b) Boxplots for vascular plant species number per sample location showing the minimum and maximum values, the range of the middle half of the scores (25th to 75th percentile) and the median and outliers, if present. (c) Cover-weighted elevational rank score $\mathrm{S}$ for each sample location, based on the elevational rank values of vascular plants as displayed in Figure 8 and calculated using the formula in [106] (see also Appendix A). 

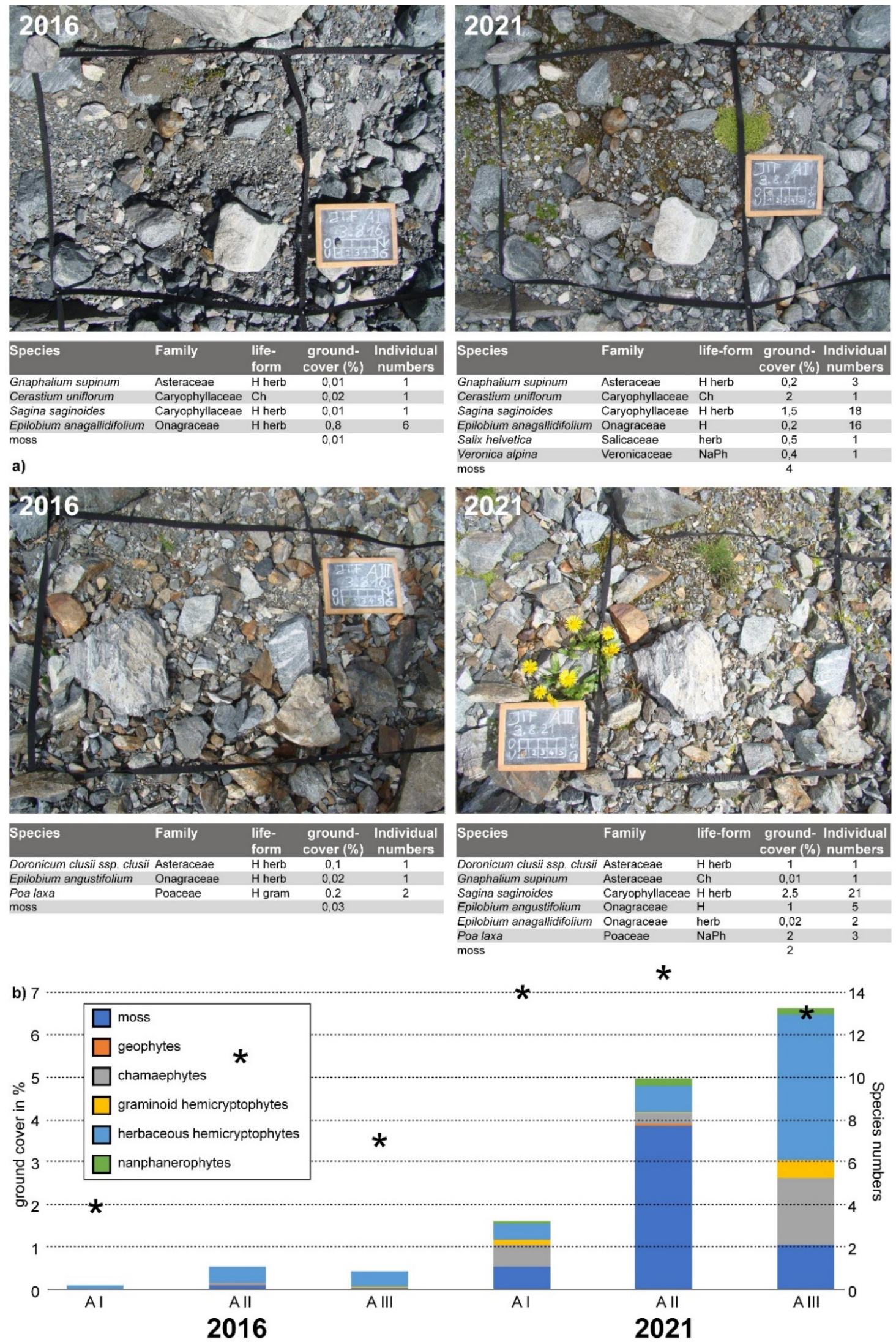

Figure 11. Rapid colonization of newly emerged supraglacial debris on Jamtalferner (European Alps, Austria): (a) illustrative photo-pairs of two $1 \mathrm{~m}^{2}$ sample plots in 2016 and 2021; (b) changes in ground cover and life-form composition (bars) along with species numbers (asterisks) of three samples AI, AII and AIII (10 $\mathrm{m}^{2}$ each) between 2016 and 2021. 


\section{DCGs as Potential Cold Stage Refugia in the Past}

An increasing number of studies focus on vegetation on DCGs [44-47,49,50]. They indicate that even a shallow debris cover allows for establishment and survival of plants. Employing the principle of uniformitarianism (sensu [111]), DCGs could have provided habitats for plants during repeated cold and warm cycles (Figure 12a) caused by climatic oscillations in the past as well.

In 2007 we hypothesized that DCGs functioned as habitats for plants during Pleistocene cold phases [45]. Before our publication there were two competing hypotheses on the fate of plants during Pleistocene ice ages [112-114]. The first, tabula rasa, theorized a complete replacement of plants to milder refugia in the foreland or farther away and a subsequent recolonization after glacier retreat, i.e., the slate (tabula) was wiped clean (rasa) by glacial ice, and plants then grew back on the clean slate. The second hypothesis is survival of plants during ice ages on nunataks, isolated unglaciated mountain peaks within extensive ice sheets that then allowed for a fast recolonization from these mountain refugia. While there are studies, primarily employing DNA analyses, in support for either one of these hypotheses, current perspectives abandon such a sort of exclusiveness. Instead, individualistic responses of species to climatic changes are assumed [115], and the existence of many different "cryptic" (micro)refugia are proposed as the key explanation for present day species distribution and genetic patterns [115-117]. Our assumption of Pleistocene plant survival on debris-covered glacier surfaces introduced a new, hitherto unrecognized cryptic microrefugia for plants, from which a post-glacial recolonization of mountain areas was possible without relying exclusively on either longdistance remigration from peripheral refugia (i.e., the tabula rasa hypothesis) or a plant survival on extremely cold and isolated ice-free areas within extended ice sheets (i.e., the nunatak hypothesis). Pleistocene DCGs were located in a much milder low-elevation climatic setting compared to high-elevation nunataks, thus offering better chances for survival for many different plant species. Glaciers in mid-latitude mountains such as the European Alps descended to the base of the mountains as piedmont glaciers [118], similar to present day Alaskan glaciers such as Malaspina or Bering. These two examples also provide insight as to the Pleistocene debris sources which were primarily the less glaciated valley entrances and outer margins of the mountain ranges (see Figure S1). In addition, basal thrusting (Figure 4) might have brought basal sediments to the surface in the lower parts of the glaciers enhancing the supraglacial debris mantle. Thus, even if the source area for supraglacial debris was limited in the center of the ice sheets during full glacial conditions, where clean-ice glaciers prevailed, and just as exist in contemporary analogues, piedmont glaciers flowing to low-elevation mountain forelands were able to accumulate a significant amount of debris on their termini. As debris sources were reduced, debris cover extent may have been proportionally less than today. Nevertheless, unglaciated rock faces and slopes above piedmont glaciers provided sufficient suitable substrate and refugia for plant growth, especially when considering the warmer temperatures at lower elevations. Pleistocene mid-latitude mountain glaciers such as those in the Alps terminated some $2000 \mathrm{~m}$ below their current position. Assuming a vertical temperature lapse rate of $0.6^{\circ} \mathrm{C} / 100 \mathrm{~m}$, this corresponds to a difference in temperature of $12{ }^{\circ} \mathrm{C}$, what is roughly the value of cooling during the last cold phase of the Pleistocene in Central Europe (Figure 12b). Thus, cold-adapted high-elevation plants of the Alps may have found comparable site conditions, in terms of both substrate (coarse debris) and climate, to their present-day natural habitats on Pleistocene DCGs (Figure 12c). With an increasing debris thickness on Pleistocene piedmont glaciers, even lower elevation taxa were able to survive on supraglacial debris, especially when considering small-scale microclimatic differentiation described by Scherrer and Körner [119]. 

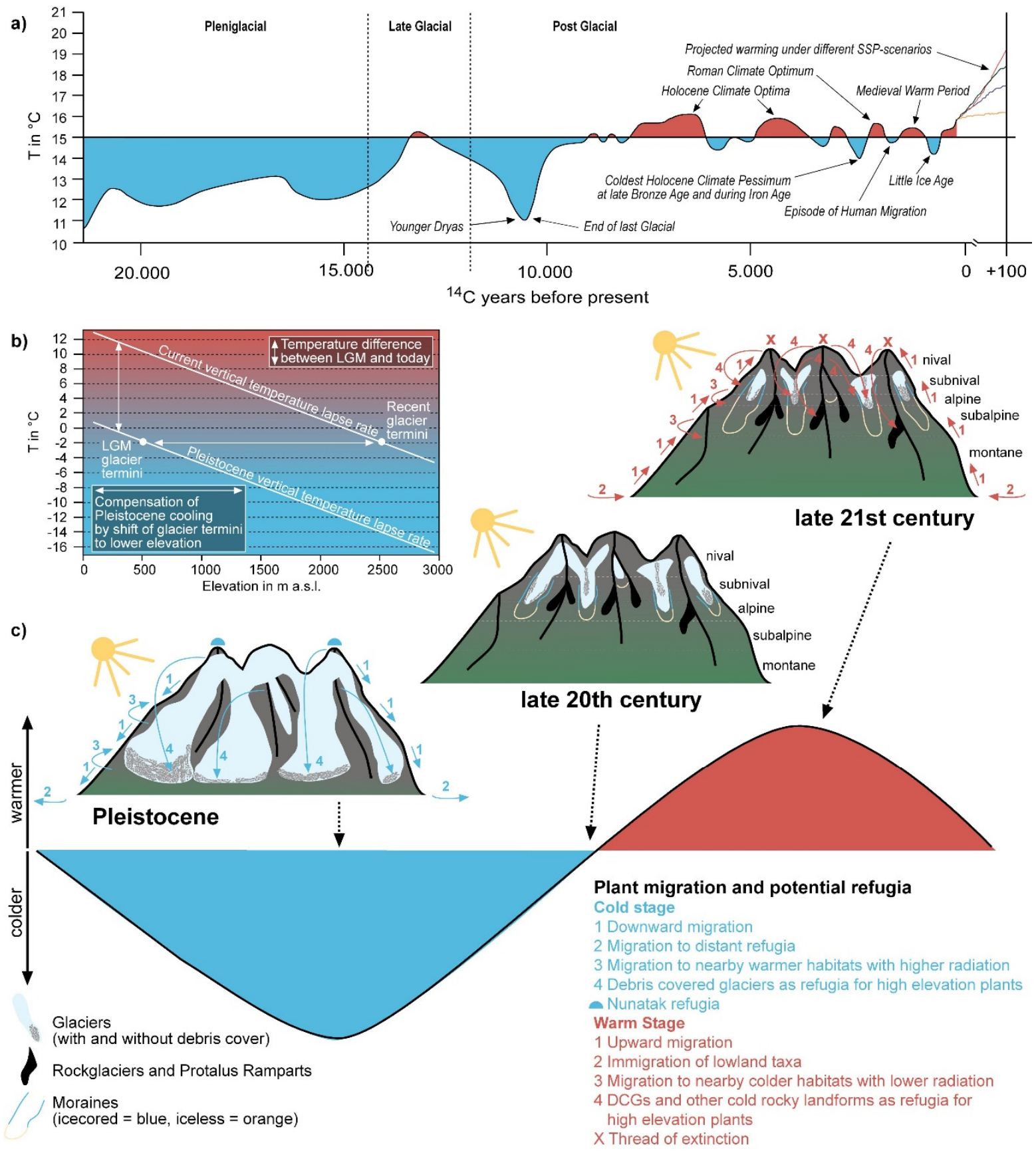

Figure 12. Plant migration and potential plant refugia under colder and warmer temperatures than today: (a) North hemispheric mean air temperature change and variability during the last 20k years (adapted and modified from [120]), together with projections under different IPCC-SSP (shared socioeconomic pathways) scenarios (according to [121]). (b) Schematic vertical temperature lapse rates today and during the last glacial maximum (LGM), illustrating the comparable thermal conditions at LGM (at lower elevations but under colder climate) and current glacier termini, making debris-covered LGM piedmont glaciers potential plant refugia temperature-wise. (c) Potential plant migration directions and refugia under colder (e.g., Pleistocene) and warmer (e.g., projected for late 21st century) conditions compared to late 20th century.

Our assumption of Pleistocene DCGs as plant refugia was recently supported by Zale et al. [122], who found macrofossil evidence of vascular plant growth on debris-covered Late Weichselian ice sheet during Greenland interstadial 1 (GI-1 or Bølling-Allerød interstadial) in Fennoscandia, three millennia before final deglaciation. For the final deglaciation phase 
the presence of shrubs (Salix div. spec., Betula div. spec. and Ericaceae div. spec.) and tree species (Larix) is reported. Comparable "plant trash" originating from supraglacial forests on Late Pleistocene ice sheets were found in lake sediments from North America [123], likewise indicating the presence of a supraglacial forest containing Picea spec., Larix laricina, Juniperus communis, Cornus stolonifera, C. canadensis, Rubus pubescens, Fragaria virginiana and Viola sp. on debris-covered dead ice remnants of the Late Pleistocene Laurentide ice sheet. Even earlier, Stephens [71] assumed that vegetation on supraglacial debris on Late Wisconsin ice in Alaska could have hastened the post-glacial extension of plant ranges.

\section{The Role of DCGs and Other Cold Rocky Landforms as Refugia under Current Climate Warming}

Based on the fact that cold-adapted high-elevation taxa are commonly found well below their natural distribution on DCGs, a complementary hypothesis was proposed: DCGs as refugia for cold-adapted taxa during Holocene warm stages [47,54,58,124]. Crucial for that kind of habitat function is a shallow debris layer, favoring cryophilic plants with a sufficiently cool root horizon. This has important implications for the survival of coldadapted high-elevation plants under current climate warming.

Climate-warming-induced upward range shift of plant species, plant communities and/or elevational belts are well-documented phenomena in high mountains globally [106,125-131]. Within an increasingly warmer world, many high-elevation plant species, whose distribution is primarily determined by cold temperatures, migrate upwards to higher colder elevations (Figure 12c) to find suitable habitats [106,127,131,132]. For species already restricted to the upper margin of the elevational relief, summit locations could easily become a trap. Ongoing climate warming is expected to cause their extinction, as they fall victim to competition from upward migrating plants from lower elevation (Figure 12c, see also $[106,127,133,134])$. For these species, alternative cold habitats in their surrounding region will enhance their chance for survival. The increasing area of glacier forelands left by the receding glaciers are assumed to provide to a certain degree suitable habitats for cryophilous species [60]. However, glacier forelands alone, for which an area gain of $0.126 \mathrm{Mio} \mathrm{km}$ is calculated under a $2.2^{\circ} \mathrm{C}$ warming scenario, are not able to compensate the area loss $\left(1.5 \mathrm{Mio} \mathrm{km}^{2}\right)$ of high-elevation ecosystems by advancing tree lines [135]. Thus, the existence of other refugia is crucial for their survival. Brighenti et al. [58] and Gentili et al. [124] introduce several additional glacial and periglacial landforms, aptly termed "cold rocky landforms" [58] with similar and/or additional functions to DCGs, contributing to a mosaic of strongly diverging microhabitats for plant (and other) life in high mountain environments [135].

Besides the already mentioned recently deglaciated glacier forelands, ice-cored and iceless moraines, nivation niches, rock glaciers (supposedly more common in dry continental climates [10]) and protalus ramparts, talus slopes along with composite debris cones and channels created by the coexistence of different erosive and depositional processes, must be taken into account as potential cold and rocky plant habitats in warming mountain environments [48]. Underground ice and/or natural convection within the debris inducing a seasonally reversible circulation pattern [58] keep these landforms cold year-round, creating habitat conditions similar to DCGs even with geomorphological processes causing a certain degree of substrate mobility. Consequently, many of the plant species mentioned for such cold rocky landforms $[47,58,124]$ are present on northern hemisphere DCGs, too. They include: Oxyria digyna on Carbon Glacier, Miage Glacier, Belvedere Glacier, Lang Glacier and Hailuogou Glacier (Gonga Shan, China); Poa alpina on Miage Glacier, Belvedere Glacier, Lang Glacier and Oytagh Glacier (Eastern Pamir, China); and Ranunculus glacialis, Leucanthemopsis alpina, Saxifraga bryoides and Linaria alpina on Miage Glacier, Belvedere Glacier and Lang Glacier of the European Alps. 


\section{Conclusions}

Cold rocky landforms including DCGs with surface and/or subsurface ice in close proximity might provide appropriate habitats for cryophilous plant species, and, if so, significantly enlarge the areal extent of potential refugia for those species. In contrast to clean-ice glaciers and snowfields, these landforms are less responsive to climate warming due to insulating effects and the thermal inertia of the debris layer $[17,58]$. Thus, these coarse-grained, more-or-less mobile and cold environments will persist despite climate warming, at least for the near future. They will provide suitable habitats for cryophilous species possessing physiological and/or physiognomic adaptations to cope with the special habitat conditions and allows them-at least in the near- to medium-term-to escape the threat of extinction by climate warming induced upward migrating taxa from lower elevation and/or the decreasing amount of available space [58,124,128]. In summary, such landforms may help to prevent both local disappearances of species and general species extinction.

Mountains in general are known to provide important refugia for organisms under a changing climate (Figure 12c), allowing for easier vertical range shifts (upward during warmer phases, downward during cooler phases) compared to the lowlands, where significantly greater distances have to be conquered to find suitable habitats. In addition, topographically (and thus microclimatically) diverse mountain terrain provides opportunity for many species to survive climatic changes due to the mosaic of strongly diverging microhabitats [135]. DCGs and other cold rocky landforms decrease the chances for mountains to become traps for the survival of plants under changing climates, in the past, present and future, as they provide refugia during both warming and cooling climates. Under warming conditions cold-adapted plant species can survive in the cold microclimate offered by DCGs and other such landforms. Under cooling and cold conditions, DCGs descend to lower elevation with milder climate and offer chances for plant survival.

Supplementary Materials: The following supporting information can be downloaded at: https: / / www.mdpi.com/article/10.3390/d14020114/s1, Figure S1: Satellite imagery of Malaspina Glacier (source: NASA, https://earthobservatory.nasa.gov/images/86767/malaspina-glacier-alaska), Table S1: Species list of Carbon Glacier (Mt. Rainier, Washington, DC, USA), Table S2: Species list of Miage Glacier (Alps, Italy), Table S3: Species List of Lang Glacier (Alps, Switzerland).

Author Contributions: Conceptualization, M.R. and T.F.; methodology, M.R., T.F. and F.G.; formal analysis, T.F. and F.G.; writing—original draft preparation, T.F.; writing—review and editing, all authors; funding acquisition, M.R. All authors have read and agreed to the published version of the manuscript.

Funding: Field sampling of data presented here was funded by the Deutsche Forschungsgemeinschaft (DFG, German Research Foundation) under grant number RI370/13-1. Vegetation sampling and data analyses for Jamtalferner (Silvretta, Tyrol, Austria) were supported by Verein GletscherKlima (Glacier-Climate Society) and Österreichische Akademie der Wissenschaften (ÖAW, Austrian Academy of Science).

Institutional Review Board Statement: Not applicable.

Data Availability Statement: The data used are available upon request to the corresponding author.

Acknowledgments: The authors are grateful to Constance I. Millar (Scientist Emerita, USDA Forest Service, Pacific Southwest Research Station, Lee Vining, CA 93541, USA) for valuable comments on an earlier version of the manuscript and to two anonymous reviewers for their suggestions which greatly improved the outcome. Biol. Eric F. Rodríguez-Rodríguez at the Herbarium Truxillense of the National University of Trujillo (HUT), Perú, helped with identification of plant species from Kinzl Glacier in the Cordillera Blanca.

Conflicts of Interest: The authors declare no conflict of interest. 


\section{Appendix A. Materials and Methods}

Vegetation data for the three mid-latitude model DCGs presented here, namely Carbon Glacier on Mount Rainier (Cascade Range, Washington, DC, USA), Miage Glacier (European Alps, Italy) and Lang Glacier (European Alps, Switzerland) were collected on quadratic $100 \mathrm{~m}^{2}$ sample sites arranged along transversal transects across the DCGs. The number of sampling sites and distance between them varied, depending on area, elevational range and terrain characteristics of the debris-covered glacier surface. Vegetation data recorded include percent ground cover of all occurring vascular plant species and the respective lifeform affiliation (therophytes $=$ annual herbaceous plants; geophytes $=$ plants with tuberous subterranean organs; hemicryptophytes = graminoid and herbaceous perennial plants; chamaephytes = woody dwarf shrubs growing less than $0.5 \mathrm{~m}$ tall; nanophanerophytes $=$ shrubs growing $0.5-2 \mathrm{~m}$ tall; microphanerophytes $=$ shrubs growing $2-5 \mathrm{~m}$ tall; mesophanerophytes $=$ trees growing $5-20 \mathrm{~m}$ tall; macrophanerophytes $=$ trees growing 20-50 $\mathrm{m}$ tall). Sampling occurred from the glacier terminus up-glacier to the uppermost occurrence of plants. In addition, site characteristics (aspect, slope angle, proportion of coarse rock and, when possible, depth of debris cover) were recorded. At Carbon Glacier, 12 transects with a total of 68 plots were sampled between 1110 and $1530 \mathrm{~m}$ a.s.l., in vertical steps of $30 \mathrm{~m}$; a sampling gap exists between 1400 and $1500 \mathrm{~m}$ a.s.l. due to an inaccessible serac zone. In addition to the DCG samples, further vegetation sampling was carried out at ten forest and ten scree slope locations next to Carbon Glacier on equally sized sample sites. At Miage Glacier a total of 17 transects with 79 plots were sampled between 1700 and $2315 \mathrm{~m}$ a.s.l, in vertical steps of mostly $50 \mathrm{~m}$. At Lang Glacier six transects with 24 plots were sampled between 2125 and $2250 \mathrm{~m}$ a.s.l. in vertical steps of $25 \mathrm{~m}$. Plant taxonomy for Carbon Glacier follows Biek [101] and for Miage and Lang Glacier, Fischer et al. [102]. Additional vegetation data come from Jamtalferner in the European Alps (Silvretta, Tyrol, Austria) where a repeated plant survey $(2016,2021)$ on species composition and ground cover on three $10 \mathrm{~m}^{2}$ samples $(5 \times 2 \mathrm{~m})$ was conducted. On Carbon Glacier also short-term surface- and soil-temperature measurements were carried out.

Vegetation data analyses include standard uni- and multivariate statistical procedures. Life-form composition is displayed separately for each transversal transect by bar graphs (Figure 10) showing the relative contribution (i.e., mean ground cover) of a particular life-form to total ground cover. Species numbers per transect are displayed by boxplots. In addition, for each transect a ground-cover-weighted elevational rank score $S$ is calculated. The elevational rank of a particular species is specified by its primarily temperature determined distribution along the elevational gradient, ranging here from montane (7) to subnival (1) (information on elevational species distribution from [101,102]). Considering all species with their respective elevational ranks and the mean ground cover per transect, a composite elevational rank score is calculated to depict changes within and differences between DCGs. Calculation is by the following equation (according to [106]):

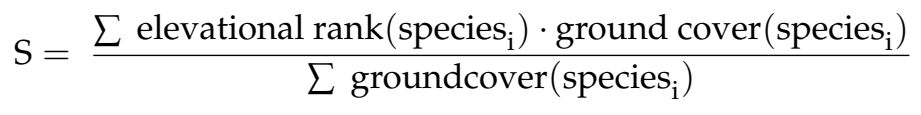

A canonical correspondence analysis (CCA) was employed to identify similarities regarding species composition between DCG samples on Carbon Glacier and samples on forest and scree slope locations in the immediate surroundings. The CCA results are displayed by an ordination scatterplot (Figure 9), arranging samples along underlying gradients. Samples are shown as symbols and explaining variables as arrows, pointing from the origin of the coordinates into the direction where samples with above-average values of the respective variable are located (Figure 9). The arrangement of samples within the ordination space indicates the floristic (dis)similarity. The CCA analysis was performed with the software Canoco 4.5 (Biometrics, Wageningen and České Budějovice). Species data were $\log$-transformed $\left(x^{\prime}=\log (x+1)\right)$ prior to CCA calculation to place the data within acceptable limits of normality $[136,137]$. 


\section{References}

1. Scherler, D.; Wulf, H.; Gorelick, N. Global assessment of supraglacial debris-cover extents. Geophys. Res. Lett. 2018, 45, 11798-11805. [CrossRef]

2. Herreid, S.; Pellicciotti, F. The state of rock debris covering Earth's glaciers. Nat. Geosci. 2020, 13, 621-627. [CrossRef]

3. Zemp, M.; Frey, H.; Gärtner-Roer, I.; Nussbaumer, S.; Hoelzle, M.; Paul, F.; Haeberli, W.; Denzinger, F.; Ahlstrom, A.P.; Anderson, B.; et al. Historically unprecedented global glacier decline in the early 21st century. J. Glaciol. 2015, 61, 745-762. [CrossRef]

4. Hugonnet, R.; McNabb, R.; Berthier, E.; Menounos, B.; Nuth, C.; Girod, L.; Farinotti, D.; Huss, M.; Dussaillant, I.; Brun, F.; et al. Accelerated global glacier mass loss in the early twenty-first century. Nature 2021, 592, 726-731. [CrossRef]

5. Farinotti, D.; Immerzeel, W.W.; de Kok, R.J.; Quincey, D.J.; Dehecq, A. Manifestations and mechanisms of the Karakoram glacier. Anomaly. Nat. Geosci. 2020, 13, 8-16. [CrossRef]

6. Haeberli, W.; Noetzli, J.; Arenson, L.; Delaloye, R.; Gärtner-Roer, I.; Gruber, S.; Isaksen, K.; Kneisel, C.; Krautblatter, M.; Phillips, M. Mountain permafrost: Development and challenges of a young research field. J. Glaciol. 2011, 56, 1043-1058. [CrossRef]

7. McColl, S.T. Paraglacial rock-slope stability. Geomorphology 2012, 153-154, 1-16. [CrossRef]

8. Stoffel, M.; Huggel, C. Effects of climate change on mass movements in mountain environments. Prog. Phys. Geog. 2012, 36, 421-439. [CrossRef]

9. Wahrhaftig, C.; Cox, A. Rock glaciers in the Alaska Range. Geol. Soc. Am. Bull. 1959, 70, 383-436. [CrossRef]

10. Barsch, D. Rockglaciers. Indicators for the Present and Former Geoecology in High Mountain Environments; (Springer Series in Physical Environment Book Series); Springer: Berlin, Germany, 1996; Volume 16.

11. Haeberli, W. Modern Research Perspectives Relating to Permafrost Creep and Rock Glaciers: A Discussion. Permafr. Periglac. 2000, 11, 290-293. [CrossRef]

12. Berthling, I. Beyond confusion: Rock glaciers as cryo-conditioned landforms. Geomorphology 2011, 131, 98-106. [CrossRef]

13. Whalley, B.; Matsuoka, N.; Sik, A.; Kereszturi, A.; Hargitai, H. Rock Glacier and Debris-Covered Glacier. In Encyclopedia of Planetary Landforms; Hargitai, H., Kereszturi, A., Eds.; Springer: New York, NY, USA, 2015; pp. 1811-1828. [CrossRef]

14. Kirkbride, M.P. Debris-Covered Glaciers. In Encyclopedia of Snow, Ice and Glaciers; Singh, V.P., Singh, P., Haritashya, U.K., Eds.; Springer: Dordrecht, The Netherlands, 2011; pp. 190-192. [CrossRef]

15. Johnson, P.G. Glacier-Rock glacier transition in the Southwest Yukon Territory, Canada. Arct. Alp. Res. 1980, 12, 195-204. [CrossRef]

16. Whalley, B.; Martin, H. Rock glaciers: II models and mechanisms. Prog. Phys. Geog. 1992, 16, 127-186. [CrossRef]

17. Anderson, R.; Anderson, L.; Armstrong, W.; Rossi, M.; Crump, S. Glaciation of alpine valleys: The glacier-Debris-covered glacier-Rock glacier continuum. Geomorphology 2018, 311, 127-142. [CrossRef]

18. Fountain, A.G.; Raymond, C.F.; Nakawo, M. International Workshop examines debris-covered glaciers. Eos 2001, 82, 261-262.

19. Nicholson, L.; Benn, D.I. Calculating ice melt beneath a debris layer using meteorological data. J. Glaciol. 2006, 52, 463-470. [CrossRef]

20. Reid, T.; Brock, B. An energy-balance model for debris-covered glaciers including heat conduction through the debris layer. J. Glaciol. 2010, 56, 903-916. [CrossRef]

21. Evatt, G.; Abrahams, I.; Heil, M.; Mayer, C.; Kingslake, J.; Michell, S.; Fowler, A.; Clark, C. Glacial melt under a porous debris layer. J. Glaciol. 2015, 61, 825-836. [CrossRef]

22. Naegeli, K.; Huss, M. Sensitivity of mountain glacier mass balance to changes in bare-ice albedo. Ann. Glaciol. 2017, 58, 119-129. [CrossRef]

23. Fyffe, C.L.; Brock, B.W.; Kirkbride, M.P.; Mair, D.W.F.; Arnold, N.S.; Smiraglia, C.; Diolaiuti, G.; Diotri, F. Do debris-covered glaciers demonstrate distinctive hydrological behaviour compared to clean glaciers? J. Hydrol. 2019, 570, 584-597. [CrossRef]

24. Ferguson, J.C.; Vieli, A. Modelling steady states and the transient response of debris-covered glaciers. Cryosphere 2021, 15, 3377-3399. [CrossRef]

25. Huo, D.; Chi, Z.; Ma, A. Modeling Surface Processes on Debris-Covered Glaciers: A Review with Reference to the High Mountain Asia. Water 2021, 13, 101. [CrossRef]

26. Mayr, E.; Hagg, W. Debris-Covered Glaciers. In Geomorphology of Proglacial Systems. Geography of the Physical Environment; Heckmann, T., Morche, D., Eds.; Springer: Cham, Switzerland, 2019. [CrossRef]

27. Rounce, D.; Hock, R.; McNabb, R.; Millan, R.; Sommer, C.; Braun, M.; Malz, P.; Maussion, F.; Mouginot, J.; Seehaus, T.; et al. Distributed Global Debris Thickness Estimates Reveal Debris Significantly Impacts Glacier Mass Balance. Geophys. Res. Lett. 2021, 48, e2020GL091311. [CrossRef] [PubMed]

28. Banerjee, A. Brief Communication: Thinning of debris-covered and debris-free glaciers in a warming climate. Cryosphere 11 2017, 133-138. [CrossRef]

29. Salerno, F.; Thakuri, S.; Tartari, G.; Nuimura, T.; Sunako, S.; Sakai, A.; Fujita, K. Debris-covered glacier anomaly? Morphological factors controlling changes in the mass balance, surface area, terminus position, and snow line altitude of Himalayan glaciers. Earth Planet Sci. Lett. 2017, 471, 19-31. [CrossRef]

30. Huo, D.; Bishop, M.P.; Bush, A.B.G. Understanding Complex Debris-Covered Glaciers: Concepts, Issues, and Research Directions. Front. Earth Sci. 2021, 9, 358. [CrossRef] 
31. Pfeffer, W.T.; Arendt, A.A.; Bliss, A.; Bolch, T.; Cogley, J.G.; Gardner, A.S.; Hagen, J.-O.; Hock, R.; Kaser, G.; Kienholz, C.; et al. The Randolph Glacier Inventory: A globally complete inventory of glaciers. J. Glaciol. 2014, 60, 537-552. [CrossRef]

32. RGI Consortium. Randolph Glacier Inventory-A Dataset of Global Glacier Outlines: Version 6.0: Technical Report, Global Land Ice Measurements from Space; Digital Media; RGI Consortium: Boulder, CO, USA, 2017. [CrossRef]

33. WGMS; NSIDC. World Glacier Inventory. Compiled and Made Available by the World Glacier Monitoring Service; Updated 2012; Zurich, Switzerland, and The National Snow and Ice Data Center: Boulder, CO, USA, 1989. [CrossRef]

34. Raup, B.; Racoviteanu, A.; Khalsa, S.J.S.; Helm, C.; Armstrong, R.; Arnaud, Y. The GLIMS geospatial glacier database: A new tool for studying glacier change. Glob. Planet Change 2007, 56, 101-110. [CrossRef]

35. GLIMS; NSIDC. Global Land Ice Measurements from Space Glacier Database; Compiled and made available by the international GLIMS community and the National Snow and Ice Data Center, updated 2018; National Snow and Ice Data Center: Boulder, CO, USA, 2005. [CrossRef]

36. GlaThiDa Consortium. Glacier Thickness Database 3.1.0; World Glacier Monitoring Service: Zurich, Switzerland, 2020. [CrossRef]

37. Welty, E.; Zemp, M.; Navarro, F.; Huss, M.; Fürst, J.J.; Gärtner-Roer, I.; Landmann, J.; Machguth, H.; Naegeli, K.; Andreassen, L.M.; et al. Worldwide version-controlled database of glacier thickness observations. Earth Syst. Sci. Data 2020, 12, $3039-3055$. [CrossRef]

38. Paul, F.; Huggel, C.; Kääb, A. Combining satellite multispectral image data and a digital elevation model for mapping debriscovered glaciers. Remote Sens. Environ. 2004, 89, 510-518. [CrossRef]

39. Brenning, A.; Trombotto, D. Logistic regression modeling of rock glacier and glacier distribution: Topographic and climatic controls in the semi-arid Andes. Geomorphology 2006, 81, 141-154. [CrossRef]

40. Brenning, A.; Grasser, M.; Friend, D.A. Statistical estimation and generalized additive modeling of rock glacier distribution in the San Juan Mountains, Colorado, USA. J. Geophys. Res. Earth 2007, 112, F02S15. [CrossRef]

41. Molnia, B.F. Satellite Image Atlas of the Glaciers of the World: Alaska; US Geological Survey Professional Paper 1386-K; U.S. Geological Survey: Reston, VA, USA, 2008; 750p.

42. Shukla, A.; Gupta, R.P.; Arora, M.K. Delineation of debris-covered glacier boundaries using optical and thermal remote sensing data. Remote Sens. Lett. 2010, 1, 11-17. [CrossRef]

43. Xie, Z.; Haritashya, U.; Asari, V.; Young, B.; Bishop, M.; Kargel, J. GlacierNet: A Deep-Learning Approach for Debris-Covered Glacier Mapping. IEEE Access 2020, 8, 83495-83510. [CrossRef]

44. Richter, M.; Fickert, T.; Grüninger, F. Pflanzen auf schuttbedeckten Gletschern—Wandernde Kuriositäten. Geoöko 2004, 25, 225-256.

45. Fickert, T.; Friend, D.; Grüninger, F.; Molnia, B.; Richter, M. Did Debris-Covered Glaciers Serve as Pleistocene Refugia for Plants? A New Hypothesis Derived from Observations of Recent Plant Growth on Glacier Surfaces. Arct. Antarct. Alp. Res. 2007, 39, 245-257. [CrossRef]

46. Pelfini, M.; Santilli, M.; Leonelli, G.; Bozzoni, M. Investigating surface movements of debris-covered Miage Glacier (Western Italian Alps) using dendroglaciological analysis. J. Glaciol. 2007, 53, 141-152. [CrossRef]

47. Caccianiga, M.; Andreis, C.; Diolaiuti, G.; D'Agata, C.; Mihalcea, C.; Smiraglia, C. Alpine debris-covered glaciers as a habitat for plant life. Holocene 2011, 21, 1011-1020. [CrossRef]

48. Millar, C.I.; Westfall, R.D.; Evenden, A.; Holmquist, J.G.; Schmidt-Gengenbach, J.; Franklin, R.S.; Nachlinger, J.; Delany, D.L. Potential climatic refugia in semi-arid, temperate mountains: Plant and arthropod assemblages associated with rock glaciers, talus slopes, and their forefield wetlands, Sierra Nevada, California, USA. Quatern. Int. 2015, 387, 106-121. [CrossRef]

49. Tampucci, D.; Citterio, C.; Gobbi, M.; Caccianiga, M. Vegetation outlines of a debris-covered glacier descending below the treeline. Plant Sociol. 2016, 53, 45-54. [CrossRef]

50. Vezzola, L.; Diolaiuti, G.; D'Agata, C.; Smiraglia, C.; Pelfini, M. Assessing glacier features supporting supraglacial trees: A case study of the Miage debris-covered Glacier (Italian Alps). Holocene 2016, 26, 1138-1148. [CrossRef]

51. Gobbi, M.; Isaia, M.; De Bernardi, F. Arthropod colonisation of a debris-covered glacier. Holocene 2011, 21, 343-349. [CrossRef]

52. Gobbi, M.; Ballarin, F.; Brambilla, M.; Compostella, C.; Isaia, M.; Losapio, G.; Maffioletti, C.; Seppi, R.; Tampucci, D.; Caccianiga, M. Life in harsh environments: Carabid and spider trait types and functional diversity on a debris-covered glacier and along its foreland. Ecol. Entomol. 2017, 42, 838-848. [CrossRef]

53. Gobbi, M. Global warning: Challenges, threats and opportunities for ground beetles (Coleoptera: Carabidae) in high altitude habitats. Acta Zool. Hung. 2020, 66, 5-20. [CrossRef]

54. Tampucci, D.; Azzoni, R.S.; Boracchi, P.; Citterio, C.; Compostella, C.; Diolaiuti, G.; Isaia, M.; Marano, G.; Smiraglia, C.; Gobbi, M.; et al. Debris-covered glaciers as habitat for plant and arthropod species: Environmental framework and colonization pattern. Ecol. Complex 2017, 32, 42-52. [CrossRef]

55. Valle, B.; Ambrosini, R.; Caccianiga, M.; Gobbi, M. Ecology of the cold-adapted species Nebria germari (Coleoptera: Carabidae): The role of supraglacial stony debris as refugium during the current interglacial period. Acta Zool. Hung. 2020, 66, 199-220. [CrossRef]

56. Franzetti, A.; Tatangelo, V.; Gandolfi, I.; Bertolini, V.; Bestetti, G.; Diolaiuti, G.; D’Agata, C.; Mihalcea, C.; Smiraglia, C.; Ambrosini, R. Bacterial community structure on two alpine debris-covered glaciers and biogeography of Polaromonas phylotypes. ISME J. 2013, 7, 1483-1492. [CrossRef] 
57. Losapio, G.; Jordán, F.; Caccianiga, M.; Gobbi, M. Structure-dynamic relationship of plant-insect networks along a primary succession gradient on a glacier foreland. Ecol. Model. 2015, 314, 73-79. [CrossRef]

58. Brighenti, S.; Hotaling, S.; Finn, D.A.; Fountain, A.G.; Hayashi, M.; Herbst, D.; Saros, J.E.; Tronstad, L.M.; Millar, C.I. Rock glaciers and related cold rocky landforms: Overlooked climate refugia for mountain biodiversity. Glob. Change Biol. Vol. 2021, 27, 1504-1517. [CrossRef]

59. Matthews, J.A. The Ecology of Recently-Deglaciated Terrain. A Geoecological Approach to Glacier Forelands and Primary Succession; Cambridge University Press: Cambridge, UK, 1992.

60. Erschbamer, B.; Caccianiga, M.S. Glacier forelands: Lessons of plant population and community development. Prog. Bot. 2017, 78, 259-284.

61. Lüdi, W. Die Pflanzengesellschaften des Lauterbrunnentales und ihre Sukzession; Beiträge zur Geobotanischen Landesaufnahme der Schweiz; Verlag: Zürich, Switzerland, 1921; Volume 9, pp. 1-364.

62. Negri, G. La vegetazione delle morene del Ghiacciaio del Lys (Monte Rosa). Boll. Del Com. Glaciol. Ital. 1934, 15, 105-172.

63. Negri, G. Osservazioni di U. Monterin su alcuni casi di invasioni delle morene galleggianti dei ghiacciai del Monte Rosa da parte della vegetazione. Nuovo G. Bot. Ital. 1935, 42, 699-712.

64. Negri, G. Nuovi dati sull'invasione delle morene galleggianti dei ghiacciai alpini da parte della vegetazione. Nuovo G. Bot. Ital. 1942, 49, 448-459.

65. Valbusa, U. Florula di due isole glaciali del Rutor con appendice morenica epiglaciale. Nuovo G. Bot. Ital. 1937, 44, 705-714.

66. Porter, P.R.; Evans, A.J.; Hodson, A.; Lowe, A.T.; Crabtree, M.D. Sediment-moss interactions on a temperate glacier: Falljökull, Iceland. Ann. Glaciol. 2008, 48, 25-31. [CrossRef]

67. Russell, I.C. An expedition to Mount St. Elias. Natl. Geogr. 1891, 3, 53-191.

68. Russell, I.C. Second Expedition to Mount St. Elias; U.S. Geological Survey 13th Annual Report Part 2; US Government Printing Office: Washington, DC, USA, 1893; pp. 1-91.

69. Tarr, R.S.; Martin, L. Alaskan Glacier Studies; National Geographic Society: Washington, DC, USA, 1914.

70. Sharp, R.P. The latest major advance of Malaspina Glacier, Alaska. Geogr. Rev. 1958, 48, 16-26. [CrossRef]

71. Stephens, F.R. A forest ecosystem on a glacier in Alaska. Arctic 1969, 22, 441-444. [CrossRef]

72. Rampton, V. Neoglacial fluctuations of the Natazhat and Klutlan glaciers, Yukon Territory, Canada. Can. J. Earth Sci. 1970, 7, 1236-1263. [CrossRef]

73. Post, A.; Streveler, G. The tilted forest: Glaciological-geological implications of vegetated neoglacial ice at Lituya Bay, Alaska. Quat. Res. 1976, 6, 111-117. [CrossRef]

74. Birks, H.J.B. The present flora and vegetation of the moraines of the Klutlan Glacier, Yukon Territory, Canada: A study in plant succession. Quat. Res 1980, 1, 60-86. [CrossRef]

75. Benn, D.I.; Evans, D.J.A. Glaciers and Glaciation; Routledge: New York, NY, USA, 2010; 802p.

76. Veblen, T.T.; Ashton, D.H.; Rubulis, S.; Lorenz, D.; Cortes, M. Nothofagus Stand Development on In-Transit Moraines, Casa Pangue Glacier, Chile. Arct. Alp. Res. 1989, 21, 144-155. [CrossRef]

77. Miehe, G. Langtang Himal_Flora und Vegetation als Klimazeiger und-zeugen im Himalaya; Dissertationes Botanicae 158; Borntaeger: Berlin, Germany; Stuttgart, Germany, 1990; 529p.

78. Hambrey, M.; Quincey, D.; Glasser, N.; Reynolds, J.; Richardson, S.; Clemmens, S. Sedimentological, geomorphological and dynamic context of debris-mantled glaciers, Mount Everest (Sagarmatha) region, Nepal. Quat. Sci Rev. 2009, 28, $2361-2389$. [CrossRef]

79. Janke, J.; Bellisario, A.; Ferrando, F. Classification of debris-covered glaciers and rock glaciers in the Andes of central Chile Geomorphology 2015, 241, 98-121. [CrossRef]

80. Evatt, G.; Mayer, C.; Mallinson, A.; Abrahams, I.; Heil, M.; Nicholson, L. The secret life of ice sails. J. Glaciol. 2017, 63, 1-14. [CrossRef]

81. Fowler, A.C.; Mayer, C. The formation of ice sails. Geophys Astro Fluid 2017, 111, 411-428. [CrossRef]

82. Ravanel, L.; Magnin, F.; Deline, P. Impacts of the 2003 and 2015 summer heat waves on permafrost-affected rock-walls in the Mont Blanc massif. Sci. Total. Environ. 2017, 609, 132-143. [CrossRef]

83. Mollaret, C.; Hilbich, C.; Pellet, C.; Flores-Orozco, A.; Delaloye, R.; Hauck, C. Mountain permafrost degradation documented through a network of permanent electrical resistivity tomography sites. Cryosphere 2019, 13, 2557-2578. [CrossRef]

84. Hartmeyer, I.; Delleske, R.; Keuschnig, M.; Krautblatter, M.; Lang, A.; Schrott, L.; Otto, J.-C. Current glacier recession causes significant rockfall increase: The immediate paraglacial response of deglaciating cirque walls. Earth Surf. Dynam. 2020, 8, 729-751. [CrossRef]

85. Van Woerkom, T.; Steiner, J.F.; Kraaijenbrink, P.D.A.; Miles, E.S.; Immerzeel, W.W. Sediment supply from lateral moraines to a debris-covered glacier in the Himalaya. Earth Surf. Dynam. 2019, 7, 411-427. [CrossRef]

86. Anderson, L.S.; Anderson, R.S. Modeling debris-covered glaciers: Response to steady debris deposition. Cryosphere 2016, $10,1105$. [CrossRef]

87. Fleischer, F.; Otto, J.-C.; Junker, R.; Hölbling, D. Evolution of debris cover on glaciers of the Eastern Alps, Austria, between 1996 and 2015. Earth Surf. Proc. Land. 2021, 46, 1673-1691. [CrossRef] 
88. Mattson, L.E.; Gardner, J.S.; Young, G.Y. Ablation on Debris Covered Glaciers: An Example from the Rakhiot Glacier, Punjab, Himalaya. In Snow and Glacier Hydrology, Proceedings of the Kathmandu Symposium, Kathmandu, Nepal, 16-21 November 1992; IAHS Publ. no. 218; IAHS: Wallingford, UK, 1993; pp. 289-296.

89. Boxall, K.; Willis, I.; Giese, A.; Liu, Q. Quantifying Patterns of Supraglacial Debris Thickness and Their Glaciological Controls in High Mountain Asia. Front. Earth Sci. 2021, 9, 504. [CrossRef]

90. Mayer, C.; Licciulli, C. The concept of steady state, cyclicity and debris unloading of debris-covered glaciers. Front. Earth Sci. 2021, 9, 710276. [CrossRef]

91. Anderson, L.; Anderson, R. Debris thickness patterns on debris-covered glaciers. Geomorphology 2018, 311, 1-12. [CrossRef]

92. Moore, P.L. Numerical Simulation of Supraglacial Debris Mobility: Implications for Ablation and Landform Genesis. Front. Earth Sci. 2021, 9, 595. [CrossRef]

93. Jumpponen, A.; Väre, H.; Mattson, K.; Ohtonen, R.; Trappe, J. Characterization of 'safe sites' for pioneers in primary succession on recently deglaciated terrain. J. Ecol. 2003, 87, 98-105. [CrossRef]

94. Marcante, S.; Erschbamer, B.; Buchner, O.; Neuner, G. Heat tolerance of early developmental stages of glacier foreland species in the growth chamber and in the field. Plant Ecol. 2014, 215, 747-758. [CrossRef]

95. Fickert, T.; Grüninger, F. High-speed colonization of bare ground-Permanent plot studies on primary succession of plants in recently deglaciated glacier forelands. Land Degrad. Dev. 2018, 29, 2668-2680. [CrossRef]

96. Eichel, J. Vegetation succession and biogeomorphic interactions in glacier forelands: Landform and Sediment Dynamics in Recently Deglaciated Alpine Landscapes. In Geomorphology of Proglacial Systems; Heckmann, T., Morche, D., Eds.; Springer: Cham, Switzerland, 2019; pp. 327-349. [CrossRef]

97. Woodward, F.I.; McKee, I.F. Vegetation and climate. Environ. Int. 1991, 17, 535-546. [CrossRef]

98. Barry, R.G. Mountain Weather and Climate, 3rd ed.; Cambridge University Press: Cambridge, UK, 2008; 532p.

99. Tackenberg, O.; Stöcklin, J. Wind dispersal of alpine plant species: A comparison with lowland species. J. Veg. Sci. 2008, 19, 109-118. [CrossRef]

100. Landolt, E.; Bäumler, B.; Erhardt, A.; Hegg, O.; Klötzli, F.A.; Lämmler, W.; Nobis, M.; Rudmann-Maurer, K.; Schweingruber, F.H.; Theurillat, J.-P.; et al. Flora Indicativa: Ökologische Zeigerwerte und Biologische Kennzeichen zur Flora der Schweiz und der Alpen; Haupt: Bern, Germany, 2010; 376p.

101. Biek, D. Flora of Mount Rainier National Park; Oregon State University Press: Corvallis, OR, USA, 2000; 506p.

102. Fischer, M.A.; Adler, W.; Oswald, K. Exkursionsflora für Österreich, Liechtenstein und Südtirol; Land Oberösterreich, Biologiezentrum der OÖ Landesmuseen: Linz, Germany, 2005; 1392p.

103. Körner, C. Alpine Plant Life, 2nd ed.; Springer: Berlin/Heidelberg, Germany; New York, NY, USA, 2003; $344 p$.

104. Bradshaw, A.D. Understanding the fundamentals of succession. In Primary Succession on Land; Miles, J., Walton, D.W.H., Eds.; Blackwell Scientific Publications: Oxford, UK, 1993; pp. 1-3.

105. Emmer, A.; Klimeš, J.; Hölbling, D.; Abad, L.; Draebing, D.; Skalák, P.; Štěpánek, P.; Zahradníček, P. Distinct types of landslides in moraines associated with the post-LIA glacier thinning: Observations from the Kinzl Glacier, Huascarán, Peru. Sci. Total Environ. 2020, 739, 139997. [CrossRef] [PubMed]

106. Gottfried, M.; Pauli, H.; Futschik, A.; Akhalkatsi, M.; Barančok, P.; Alonso, J.L.B.; Coldea, G.; Dick, J.; Erschbamer, B.; Calzado, M.R.F.; et al. Continent-wide response of mountain vegetation to climate change. Nat. Clim. Change 2012, 2, 111-115. [CrossRef]

107. Lawrence, D.B. Primary versus secondary succession at Glacier Bay National Monument, southeastern Alaska. In Proceedings of the First Conference on Scientific Research in the National Parks, Orleans, LA, USA, 9-12 November 1976; Transactions and Proceedings Series No. 5.; United States Department of the Interior, National Park Service: Washington, DC, USA, 1979; pp. 213-224.

108. Fischer, A. Personal communication on subsurface ice on Jamtalferner; Silvretta: Tyrol, Austria, 2021.

109. Cannone, N.; Diolaiuti, G.; Guglielmin, M.; Smiraglia, C. Accelerating climate change impacts on alpine glacier forefield ecosystems in the European Alps. Ecol. Appl. 2008, 18, 637-648. [CrossRef]

110. Fischer, A.; Fickert, T.; Schwaizer, G.; Patzelt, G.; Groß, G. Vegetation dynamics in Alpine glacier forelands tackled from space. Sci. Rep. 2019, 9, 13918. [CrossRef]

111. Gould, S.J. Is uniformitarianism necessary? Am. J. Sci. 1965, 263, 223-228. [CrossRef]

112. Ives, J.D. Biological refugia and the nunatak hypothesis. In Arctic and Alpine Environments; Ives, J.D., Barry, R.G., Eds.; Methuen: London, UK, 1974; pp. 605-636.

113. Stehlik, I. Nunataks and peripheral refugia for alpine plants during Quaternary glaciation in the middle parts of the Alps. Bot. Helv. 2000, 110, 25-30.

114. Brochmann, C.; Gabrielsen, T.; Nordal, I.; Landvik, J.; Elven, R. Glacial Survival or tabula rasa? The History of North Atlantic Biota Revisited. Taxon 2003, 52, 417-450. [CrossRef]

115. Stewart, J.R.; Lister, A.M.; Barnes, I.; Dalen, M. Refugia revisited: Individualistic response of species in space and time. Proc. R. Soc. B: Biol. Sci. 2009, 277, 661-671. [CrossRef]

116. Birks, H.J.B.; Willis, K.J. Alpines, trees, and refugia in Europe. Plant Ecol. Divers. 2008, 1, 147-160. [CrossRef]

117. Gavin, D.; Fitzpatrick, M.; Gugger, P.; Heath, K.; Rodríguez-Sánchez, F.; Dobrowski, S.; Hampe, A.; Hu, F.; Ashcroft, M.; Bartlein, P.; et al. Climate refugia: Joint inference from fossil records, species distribution models and phylogeography. N. Phytol. 2014, 204, 37-54. [CrossRef] [PubMed] 
118. Seguinot, J.; Ivy-Ochs, S.; Jouvet, G.; Huss, M.; Funk, M.; Preusser, F. Modelling last glacial cycle ice dynamics in the Alps. Cryosphere 2018, 12, 3265-3285. [CrossRef]

119. Scherrer, D.; Körner, C. Topographically controlled thermal habitat differentiation buffers alpine plant diversity against climate warming. J. Biogeogr. 2011, 38, 406-416. [CrossRef]

120. Schönwiese, C. Klimaänderungen: Daten, Analysen, Prognosen; Springer: Berlin/Heidelberg, Germany, 1995; 224p.

121. O’Neill, B.; Kriegler, E.; Ebi, K.; Kemp-Benedict, E.; Riahi, K.; Rothman, D.; van Ruijven, B.; Vuuren, D.; Birkmann, J.; Kok, K.; et al. The roads ahead: Narratives for shared socioeconomic pathways describing world futures in the 21st century. Glob. Env. Chang. 2015, 42, 169-180. [CrossRef]

122. Zale, R.; Huang, Y.-T.; Bigler, C.; Wood, J.R.; Dalén, L.; Wang, X.-R.; Segerström, U.; Klaminder, J. Growth of plants on the Late Weichselian ice-sheet during Greenland interstadial-1? Quat. Sci Rev 2018, 185, 222-229. [CrossRef]

123. Wright, H.E.; Stefanova, I. Plant trash in the basal sediments of glacial lakes. Acta Palaeobot. 2004, 44, 141-146.

124. Gentili, R.; Baroni, C.; Caccianiga, M.; Armiraglio, S.; Ghiani, A.; Citterio, S. Potential warm-stage microrefugia for alpine plants: Feedback between geomorphological and biological processes. Ecol. Complex 2015, 21, 87-99. [CrossRef]

125. Parolo, G.; Rossi, G. Upward migration of vascular plants following a climate warming trend in the Alps. Basic Appl. Ecol. 2008, 9 , 100-107. [CrossRef]

126. Chen, I.-C.; Hill, J.; Ohlemüller, R.; Roy, D.B.; Thomas, C. Rapid Range Shifts of Species Associated with High Levels of Climate Warming. Science 2011, 333, 1024-1026. [CrossRef]

127. Pauli, H.; Gottfried, M.; Dullinger, S.; Abdaladze, O.; Akhalkatsi, M.; Benito Alonso, J.-L.; Coldea, G.; Dick, J.; Erschbamer, B.; Calzado, R.F.; et al. Recent plant diversity changes on Europe's mountain summits. Science 2012, 336, 353-355. [CrossRef]

128. Carlson, B.; Georges, D.; Rabatel, A.; Randin, C.; Renaud, J.; Delestrade, A.; Zimmermann, N.; Choler, P.; Thuiller, W. Accounting for tree line shift, glacier retreat and primary succession in mountain plant distribution models. Divers. Distrib. 2014, 20, 1379-1391. [CrossRef]

129. Cannone, N.; Pignatti, S. Ecological responses of plant species and communities to climate warming: Upward shift or range filling processes? Clim. Change 2014, 123, 201-214. [CrossRef]

130. Lenoir, J.; Svenning, J.C. Climate-related range shifts-A global multidimensional synthesis and new research directions. Ecography 2015, 38, 15-28. [CrossRef]

131. Steinbauer, M.; Grytnes, J.A.; Jurasinski, G.; Kulonen, A.; Lenoir, J.; Pauli, H.; Rixen, C.; Winkler, M.; Bardy-Durchhalter, M.; Barni, E.; et al. Accelerated increase in plant species richness on mountain summits is linked to warming. Nature 2018, 556, 231-234. [CrossRef] [PubMed]

132. Lenoir, J.; Gégout, J.C.; Marquet, P.A.; de Ruffray, P.; Brisse, H. A significant upward shift in plant species optimum elevation during the 20th century. Science 2008, 320, 1768-1771. [CrossRef]

133. Engler, R.; Randin, C.F.; Thuiller, W.; Dullinger, S.; Zimmermann, N.E.; Araújo, M.B.; Pearman, P.B.; Lay, G.L.; Piedallu, C.; Albert, C.H.; et al. 21st century climate change threatens mountain flora unequally across Europe. Glob. Change Biol. 2011, 17, 2330-2341. [CrossRef]

134. Dullinger, S.; Gattringer, A.; Thuiller, W.; Moser, D.; Zimmermann, N.E.; Guisan, A.; Willner, W.; Plutzar, C.; Leitner, M.; Mang, T.; et al. Extinction debt of high-mountain plants under twenty-first-century climate change. Nat. Clim. Change 2012, 2, 619-622. [CrossRef]

135. Körner, C.; Hiltbrunner, E. Why is the Alpine Flora Comparatively Robust against Climatic Warming? Diversity 2021, 13, 383. [CrossRef]

136. Ter Braak, C.J.F.; Šmilaur, P. CANOCO for Windows Version 4.5; Biometris, Plant Research International: Wageningen, The Netherlands, 2002.

137. Lepš, J.; Šmilauer, P. Multivariate Analysis of Ecological Data Using CANOCO; Cambridge University Press: New York, NY, USA, 2003. 